\title{
Blocking Autophagy in Oligodendrocytes Limits Functional Recovery after Spinal Cord Injury
}

\author{
Sujata Saraswat Ohri, ${ }^{1,2}$ Andrew N. Bankston, ${ }^{1,2}$ - S. Ashley Mullins, ${ }^{1,2}$ Yu Liu, ${ }^{1,2}$-Kariena R. Andres, ${ }^{1,2}$ \\ ().Jason E. Beare, ${ }^{1,5}$ Russell M. Howard, ${ }^{1,2}$ Darlene A. Burke, ${ }^{1,2}$-Amberly S. Riegler, ${ }^{1,2}$ Allison E. Smith, ${ }^{1,2}$ \\ Michal Hetman, ${ }^{1,2,3,4}$ and ${ }^{-S}$ Scott R. Whittemore ${ }^{1,2,3,4}$ \\ ${ }^{1}$ Kentucky Spinal Cord Injury Research Center, Departments of ${ }^{2}$ Neurological Surgery, ${ }^{3}$ Pharmacology \& Toxicology, ${ }^{4}$ Anatomical Sciences \& Neurobiology, \\ and ${ }^{5}$ Cardiovascular Innovation Institute, University of Louisville, School of Medicine, Louisville, Kentucky 40292
}

Autophagy mechanisms are well documented in neurons after spinal cord injury (SCI), but the direct functional role of autophagy in oligodendrocyte (OL) survival in SCI pathogenesis remains unknown. Autophagy is an evolutionary conserved lysosomal-mediated catabolic pathway that ensures degradation of dysfunctional cellular components to maintain homeostasis in response to various forms of stress, including nutrient deprivation, hypoxia, reactive oxygen species, DNA damage, and endoplasmic reticulum (ER) stress. Using pharmacological gain and loss of function and genetic approaches, we investigated the contribution of autophagy in OL survival and its role in the pathogenesis of thoracic contusive SCI in female mice. Although upregulation of Atg5 (an essential autophagy gene) occurs after SCI, autophagy flux is impaired. Purified myelin fractions of contused $8 \mathrm{~d}$ post-SCI samples show enriched protein levels of LC3B, ATG5, and BECLIN 1. Data show that, while the nonspecific drugs rapamycin (activates autophagy) and spautin 1 (blocks autophagy) were pharmacologically active on autophagy in vivo, their administration did not alter locomotor recovery after SCI. To directly analyze the role of autophagy, transgenic mice with conditional deletion of Atg5 in OLs were generated. Analysis of hindlimb locomotion demonstrated a significant reduction in locomotor recovery after SCI that correlated with a greater loss in spared white matter. Immunohistochemical analysis demonstrated that deletion of $\operatorname{Atg} 5$ from OLs resulted in decreased autophagic flux and was detrimental to OL function after SCI. Thus, our study provides evidence that autophagy is an essential cytoprotective pathway operating in OLs and is required for hindlimb locomotor recovery after thoracic SCI.

Key words: autophagy; oligodendrocytes; spinal cord injury

Significance Statement

This study describes the role of autophagy in oligodendrocyte (OL) survival and pathogenesis after thoracic spinal cord injury (SCI). Modulation of autophagy with available nonselective drugs after thoracic SCI does not affect locomotor recovery despite being pharmacologically active in vivo, indicating significant off-target effects. Using transgenic mice with conditional deletion of Atg5 in OLs, this study definitively identifies autophagy as an essential homeostatic pathway that operates in OLs and exhibits a direct functional role in SCI pathogenesis and recovery. Therefore, this study emphasizes the need to discover novel autophagyspecific drugs that specifically modulate autophagy for further investigation for clinical translation to treat SCI and other CNS pathologies related to OL survival.

\section{Introduction}

In the United States, $>10,000$ people suffer from a traumatic spinal cord injury (SCI) yearly, and the current number of people

\footnotetext{
Received March 12, 2017; revised May 15, 2018; accepted May 17, 2018.

Author contributions:S.S.O., M.H., and S.R.W. designed research;S.S.O., A.N.B., S.A.M., Y.L., K.R.A., J.E.B., A.S.R., and A.E.S. performed research; S.S.O., R.M.H., and D.A.B. analyzed data; S.S.O. wrote the paper.

This work was supported by NIH-NINDS NS045734, NIH-NIGMS GM10350, Norton Healthcare, the Kentucky Spinal Cord and Head Injury Research Trust, and Commonwealth of Kentucky Research Challenge for Excellence Trust Fund to S.R.W. We thank Christine Nunn for surgical assistance and animal care; and Johnny Morehouse for BMS analyses.

The authors declare no competing financial interests.
}

living with paralysis is $>6$ million (www.christopherreeve.org). Effective clinical therapy after SCI remains elusive despite extensive research endeavors and technological advances. The complex pathophysiology after SCI involves the primary injury phase and a secondary injury cascade that progresses from hours to

Correspondence should be addressed to either Dr. Scott R. Whittemore or Dr. Sujata Saraswat Ohri, Kentucky Spinal Cord Injury Research Center, Department of Neurological Surgery, University of Louisville, School of Medicine, MDR 616, 511 South Floyd Street, Louisville, KY 40202, E-mail: swhittemore@louisville.edu or sujata.saraswat@louisville.edu.

DOI:10.1523/JNEUROSCI.0679-17.2018

Copyright $\odot 2018$ the authors $\quad 0270-6474 / 18 / 385900-13 \$ 15.00 / 0$ 
months. Critical issues that need to be addressed include reducing the secondary phase of cell death (Bareyre, 2008; Coutts and Keirstead, 2008), replacement of lost motor, propriospinal and CPG neurons (Enzmann et al., 2006; Kulbatski et al., 2008), remyelination of demyelinated and/or regenerating axons (Hesp et al., 2015), regeneration of severed axons by stimulating regenerative axonal sprouting and obviating the nonpermissive terrain (Fawcett, 2006; Yoon and Tuszynski, 2012), and finally enhancing the inherent neuroplasticity through rehabilitation/retraining (Alluin et al., 2014; Dietz and Fouad, 2014). Therapeutic interventions that abrogate secondary cell death mechanisms during the acute phase of SCI are essential for limiting the spread of the secondary injury phase and continued functional deficits after SCI.

The endoplasmic reticulum (ER) stress response (ERSR) is an evolutionarily conserved homoeostatic pathway that is initiated to reduce global protein synthesis and induce the synthesis of chaperones/proteins to increase the capacity of the ER to fold its client proteins. However, when the function of the ER cannot be restored due to excessive or sustained ER stress, removal of the affected cells occurs by apoptosis and ER-associated degradation (Sano and Reed, 2013). Recent studies showed the involvement of the ERSR in neural cell death and recovery after moderate contusive thoracic SCI in rats (Penas et al., 2007), mice (Saraswat Ohri et al., 2011), and after hemisection SCI in mice (Valenzuela et al., 2012). Importantly, partial restoration of ER homeostasis by inhibiting the proapoptotic ERSR-activated protein kinase RNA (PKR)-like kinase (PERK)/C/EBP (CCAAT enhancer binding protein) homologous protein ( $\mathrm{CHOP}$ ) axis using genetic (Saraswat Ohri et al., 2011) or pharmacological (Saraswat Ohri et al., 2013) intervention showed significant improvement of hindlimb locomotion in these rodent models and implicated oligodendrocyte $(\mathrm{OL})$ survival as a potential mechanism.

ER stress is also a potent inducer of autophagy (Yorimitsu et al., 2006; Kouroku et al., 2007). Autophagy is a basic catabolic, lysosomal-mediated mechanism that involves degradation of unnecessary or dysfunctional cellular components (Kundu and Thompson, 2008). During this process, targeted cytoplasmic constituents are isolated from the rest of the cell within a doublemembrane vesicle known as an autophagosome (Eskelinen, 2005; Eskelinen and Saftig, 2009). Autophagosomes mature by fusing with lysosomes to form autolysosomes, leading to degradation of the inner membrane and cargo and recycling of their components to the cytoplasm (Eskelinen, 2005).

Multiple laboratories have studied autophagy after SCI, and the data are inconsistent (Kanno et al., 2009, 2011; Hu et al., 2010; Chen et al., 2013). Improvement in hindlimb locomotion was reported after pharmacologically both enhancing autophagy with the nonspecific drug rapamycin (Sekiguchi et al., 2012; Chen et al., 2013) or blocking autophagy with ATP (Hu et al., 2010) or 3-methyladenine (Walker et al., 2012) after a thoracic SCI. Hu et al. (2010) saw no effect of rapamycin. Most importantly, none of these studies examined effects on spared white matter (SWM), which is the single variable that optimally correlates with chronic functional recovery after this lesion (Basso et al., 2006). As thoracic contusive SCI is predominantly a white matter injury and neuronal loss does not correlate with functional recovery (Magnuson et al., 2005), the direct role of autophagy in thoracic SCI pathogenesis, OL survival and functional recovery after SCI remains unresolved. In this study, using OL-specific Plp-cre $e^{E R T 2+/+}: A \operatorname{tg} 5^{f l / f l}$ (an essential autophagy gene) transgenic mice, we demonstrate that autophagy is an important cytoprotective, homeostatic pathway operating in OLs and is required for improved hindlimb locomotor function after thoracic SCI.

\section{Materials and Methods}

Animals. All animal procedures were performed according to the Public Health Service Policy on Humane Care and Use of Laboratory Animals, Guide for the care and use of laboratory animals (Institute of Laboratory Animal Resources, National Research Council, 1996) and with the approval of the University of Louisville Institutional Animal Care and Use Committee and the Institutional Biosafety Committee. Wild-type (WT) C57BL/6 female mice (6-8 weeks old) were obtained from Envigo, and $P l p-c r e^{E R T 2}$ (proteolipid protein) mice were acquired from The Jackson Laboratory (Plp-cre-B6.Cg-Tg (Plp1-Cre/ERT) 3Pop/J, catalog \#5975). $\operatorname{Atg} 5^{f l f l}$ mice were obtained from Myok Noboru (Mizushima; Atg5B6.129S-Atg5, catalog \#RBRCC02975) and rederived by Taconic. Transgenic mice were generated by crossing $A \operatorname{tg} 5^{f l f l}$ with $P l p-C r e^{E R T 2}$, thus restricting the expression of the transgene primarily in myelinating OLs in the CNS (Wight et al., 1993; Fuss et al., 2001). PLP is expressed earlier than MBP during development, beginning during embryonic life and at early developmental stages of OL lineage (Wight et al., 1993; Mallon et al., 2002).

SCI and injections. Mice were anesthetized by an intraperitoneal injection of $0.4 \mathrm{mg} / \mathrm{g}$ body weight Avertin (2,2,2-tribromoethanol in $0.02 \mathrm{ml}$ of $1.25 \%$ 2-methyl-2-butanol in saline, Sigma-Aldrich). Lacri-Lube ophthalmic ointment (Allergen) was used to prevent drying of eyes. Gentamycin $(50 \mathrm{mg} / \mathrm{kg}$; Boehringer Ingelheim) was subcutaneously administered to reduce infection. A laminectomy was done at the T9 vertebrae, and moderate contusion injuries (50 kdyne force $/ 400-600 \mu \mathrm{m}$ displacement) were performed using the IH impactor (Scheff et al., 2003) (Infinite Horizons) as described previously (Saraswat Ohri et al., 2011). Sham animals that received T9 laminectomy only were used as experimental controls.

While rapamycin (autophagy activator) has been used in multiple studies, spautin 1 (autophagy inhibitor) has not been used in vitro or in vivo to study OL function. Therefore, the drug doses and frequency of administration were selected based on published studies on rapamycin (Sekiguchi et al., 2012; Chen et al., 2013) and pilot experiments performed in our laboratory for spautin 1 . Rapamycin or spautin $1(1 \mathrm{mg} / \mathrm{kg}$ in PBS containing 10\% FBS and 5\% DMSO) or vehicle was administered by an intraperitoneal injection immediately after surgery followed by intraperitoneal injections for 3 consecutive days. After surgery, mice were given $1 \mathrm{cc}$ of sterile saline (s.c.), $0.1 \mathrm{cc}$ of gentamycin (s.c.) on the day of surgery and third and fifth day after surgery, and $0.1 \mathrm{cc}$ buprenorphine (s.c.) on the day of surgery and for next $2 \mathrm{~d}$. Mice were placed on a heating pad until full recovery from anesthesia. Postoperative care included manual expression of bladders twice a day for 7-10 d or until spontaneous voiding returned.

Behavioral assessment. Open field Basso Mouse Scale (BMS) locomotor analyses were performed before injury for each animal to determine the baseline scores and weekly following SCI for 6 weeks exactly as defined previously (Basso et al., 2006; Saraswat Ohri et al., 2011). All raters were trained by Dr. Basso and colleagues at the Ohio State University and were blind to the animal treatment groups.

Analysis of spared white matter. Six weeks after SCI, vehicle- and tamoxifen-treated $P l p-c r e^{E R T 2+/+}: A t g 5^{f l f l}$ mice were perfused with $4 \%$ $\mathrm{PFA}$, and $5 \mathrm{~mm}$ of spinal cord spanning the injury epicenter was dissected out and stored in $4 \%$ PFA overnight at $4^{\circ} \mathrm{C}$. The cords were cryoprotected in $30 \%$ sucrose for at least $3 \mathrm{~d}$ at $4^{\circ} \mathrm{C}$, blocked, sectioned transversely at 20 $\mu \mathrm{M}$, and stored at $-80^{\circ} \mathrm{C}$. Eriochrome cyanine was used to stain myelin to detect the extent of spared white matter at the injury epicenter (Saraswat Ohri et al., 2011).

FluoroMyelin staining and quantification. Tissue sections were derived from 10 or $50 \mathrm{~d}$ post-Veh- and Tx-treated $P l p-c r e^{E R T 2+/+}: A t g 5^{f l / f l}$ mice. FluoroMyelin Red stain (Thermo Fisher Scientific) was used to distinguish myelinated from unmyelinated spinal cord axons. Tissue sections were blocked for $30 \mathrm{~min}$ in 50\% normal donkey serum in PBS. After rinsing with PBS, sections were then incubated with FluoroMyelin Red (1:300 in PBS) for $20 \mathrm{~min}$. Sections were then washed with PBS three times for $10 \mathrm{~min}$. Coverslips were mounted using Fluoromount. Images 
were captured using a Nikon Eclipse TE 300 inverted microscope with a spot CCD camera. Exposure times remained identical across all images. Fifteen sections were analyzed from each mouse. White matter was traced using Photoshop for area and intensity analysis.

Myelin purification. Spinal cord $(5 \mathrm{~mm})$ from sham and T9-injured mice (3/group) was dissected and homogenized in buffer (15\% w/v: 10 mм HEPES, pH 7.4, 0.25 м sucrose, 3 mм DTT) on ice. Samples were centrifuged at $500 \times g$ for $5 \mathrm{~min}$, and the supernatant was transferred to new tubes. The postnuclear supernatant was adjusted to $1.4 \mathrm{M}$ sucrose ( 9 $\mathrm{ml}$ final) without changing the HEPES or DTT concentration. Crude and purified myelin fractions were then isolated (Larocca and Norton, 2006).

Tissue processing and immunohistochemistry. Longitudinal spinal cord sections were immunostained and imaged as previously described (Saraswat Ohri et al., 2011). Primary antibodies used were cleaved caspase 3 (CC3; rabbit, 1:50, Cell Signaling Technology), PDGFRa (rat, 1:50, Millipore), APC (mouse, 1:200, Calbiochem), CHOP (mouse, 1:200, Invitrogen), Olig2 (rabbit, 1:200, Millipore), p62 (mouse, 1:50, Abnova), CNPase (mouse, 1:200, Biolegend), and Ki67 (human, 1:200, BD Pharm). Secondary antibodies comprised of Alexa488 (rabbit, Invitrogen) and Alexa rhodamine red (rat), Alexa647, Alexa405, Alexa Tritc (chicken), Alexa AMCA (sheep) from Jackson ImmunoResearch Laboratories. In Elements software (Nikon Instruments), an ROI was drawn around an area including both the injury epicenter and a penumbral region $500 \mu \mathrm{m}$ rostral and $500 \mu \mathrm{m}$ caudal of epicenter. A rectangular grid graticule overlay with $150 \mu \mathrm{m} \times 150 \mu \mathrm{m}$ boxes was created within the ROI. Cells positive for each marker were counted from every fourth box; cells were counted if they were fully contained within the box being counted or touching the top and/or left side of the box. Following cell counts, the percentage of cells positive for each marker was calculated. Confocal imaging was performed using an FV1000 confocal microscope (Olympus America) equipped with 405, 488, 543, and 635 laser lines. Representative confocal stacks ( $1 \mu \mathrm{m}$ step size) were captured at $60 \times$ magnification and volume rendered using Amira software (Visualization Sciences Group).

Mouse oligodendrocyte precursor cell ( $m O P C$ ) isolation. Mouse cortical OPCs (mOPCs) were isolated from whole brains of WT and Plp$C r e^{E R T 2+/+}:$ Atg $5^{f l / f l}$ mice pups at postnatal day 5-7 as previously described (Dincman et al., 2012). Briefly, tissue was dissociated using the Neural Tissue Dissociation Kit (Miltenyi Biotec) according to the manufacturer's instructions. OPC-A media was prepared by adding $2.1 \mathrm{~g} / \mathrm{L}$ $\mathrm{NaHCO}_{3}$ (Sigma-Aldrich) to DMEM-F12 without HEPES powder (Invitrogen) and supplemented with $\mathrm{N} 2$ supplement (1\%), B27 supplement (2\%), penicillin/streptomycin (1\%, Invitrogen), BSA (0.01\%, SigmaAldrich), $40 \mathrm{ng} / \mathrm{ml} \mathrm{FGF2} \mathrm{(Millipore),} \mathrm{and} 20 \mathrm{ng} / \mathrm{ml}$ PDGF $\alpha$ (SigmaAldrich). OPCs were enriched with O4 hybridoma (Developmental Studies Hybridoma Bank) using magnetic cell sorting with rat antimouse IgM magnetic beads ( $10 \%$ in magnetic cell sorting buffer). The average yield obtained was $8-10 \times 10^{6}$ cells/brain with a viability of $85 \%-95 \%$. A total of $9000-15,000$ cells $/ \mathrm{cm}^{2}$ cells were seeded on a PDL/ laminin-coated $10 \mathrm{~cm}$ tissue culture dish, and incubated at $37^{\circ} \mathrm{C}, 5 \% \mathrm{CO}_{2}$ for maintenance.

$q P C R$. Total RNA was extracted from treated mOPCs from WT and $P l p-c r e^{E R T 2+/+}: A \operatorname{tg} 5^{f l / f l}$ mice, injury epicenter $(5 \mathrm{~mm})$ from spinal cord tissue of sham, vehicle, spautin 1- and rapamycin-contused WT mice $\left(n=4\right.$ /group) and vehicle- and tamoxifen-treated $P l p-c r e e^{E R T 2+/+}$ : Atg $5^{f l f l}$ mice using Trizol (Invitrogen) based on the manufacturer's instructions. RNA was quantified by UV spectroscopy, and its integrity was confirmed on an ethidium bromide-stained formaldehyde agarose gel. cDNA was synthesized with $1 \mu \mathrm{g}$ of total RNA using the High Capacity cDNA Synthesis Kit (Applied Biosystems) in a $20 \mu \mathrm{l}$ reaction volume. As controls, mixtures containing all components except the reverse transcriptase enzyme were prepared and treated similarly. All cDNAs and control reactions were diluted $10 \times$ with water before using as a template for qPCR.

qPCR was performed using an ABI 7900HT Real-time PCR instrument (Applied Biosystems). Briefly, diluted cDNAs were added to TaqMan universal PCR master mix (Applied Biosystems) and run in triplicate. Target and reference gene PCR amplification was performed in separate tubes with Assay on Demand primers (Applied Biosystems) as follows: Ambra 1 (Mm00554370_m1), Atg5 (Mm00504340_m1), Atf4 (Mm00515324_m1), Beclin 1 (Mm01265461_ml), Chop (Mm01135937_ g1), Edem1 (Mm00551797_m1), Gadd34 (Mm00492555_m1), Grp78 (Mm01333323_g1), Perk (Mm01182080_m1) and Xbp1 (Mm00457359_m1). RNA levels were quantified using the $\Delta \Delta$ CT method. Expression values obtained from triplicate runs of each cDNA sample were normalized to triplicate values for Gapdh (reference gene) from the same cDNA preparation. Transcript levels were expressed as fold changes compared with respective levels in sham controls.

Western blot analyses. Protein lysates were prepared from mOPCs or 5 $\mathrm{mm}$ contused spinal cord tissue isolated from sham and injury epicenter of WT and $P l p-c r e e^{E R T 2+/+}: A \operatorname{tg} 5^{f l / f l}$ mice at $24 \mathrm{~h}$ after injury in protein lysis solution (20 mм Tris, pH-6.8, $137 \mathrm{~mm} \mathrm{NaCl}, 25 \mathrm{~mm}$ B-glycerophosphate, $2 \mathrm{~mm}$ NaPPi, 2 mm EDTA, 1 mm Na $\mathrm{VO}_{4}$, 1\% Triton X-100, 10\% glycerol, protease inhibitor, $0.5 \mathrm{~mm}$ DTT, $1 \mathrm{~mm}$ PMSF). The BCA kit (Pierce) was used to quantify the protein lysates. Equal concentrations of proteins were separated on SDS-PAGE gels and transferred to nitrocellulose membrane (Schleicher \& Schuell) and processed as described previously (Saraswat Ohri et al., 2011).

MTT assay. mOPCs were seeded in 96-well plates and treated with various concentrations of spautin 1 or rapamycin as indicated in the presence of $0.025 \mu \mathrm{g} / \mathrm{ml}$ tunicamycin (Tm) for $24 \mathrm{~h}$. mOPC survival was assayed by measuring the conversion of tetrazolium, MTT (SigmaAldrich) to formazan at a wavelength of $570 \mathrm{~nm}$ as previously described (Hetman et al., 1999).

Experimental design and statistical analysis. All qPCR and Western analyses were performed using the one-way ANOVA between groups procedure followed by Tukey HSD post hoc $t$ tests for multiple comparisons. Independent $t$ tests between means with equal variance were used to compare the cell counts between the sham and T9 contused WT mice and vehicle- and tamoxifen-treated $P l p-c r e^{E R T 2+/+}: A \operatorname{tg} 5^{f l f l}$ mice at at $72 \mathrm{~h}$ after SCI. Means of experimental groups normalized to controls were compared with shams $(1.0 \pm 0)$ or controls in MTT experiments $(100 \pm 0 \%)$ using one-sample $t$ tests versus 1 or 100 , respectively. Repeated-measures ANOVA with a group effect followed by Bonferroni post hoc $t$ tests were performed on BMS scores assessed after injury. Data are reported as mean $\pm \mathrm{SD}$. Analyses were performed using SPSS, version 25 (IBM).

\section{Results}

\section{SCI leads to dysregulated autophagic flux despite enhanced} autophagy gene expression

Moderate contusive SCI in rodents causes acute activation of the ERSR (Penas et al., 2007; Saraswat Ohri et al., 2011, 2013). To address whether autophagy is similarly affected, RNA was isolated from the injury epicenter of moderately contused C57BL/6 female mice at $\mathrm{T} 9$ and analyzed for the relative expression of the essential autophagy genes: Ambra, Atg5, and Beclin 1 at $72 \mathrm{~h}$ (acute) and week 1 (subacute) after SCI. Data show significant upregulation of $\operatorname{Atg} 5$ ( $72 \mathrm{hpi}, t=13.5, \mathrm{df}=2, p=0.005 ; 1 \mathrm{wpi}$, $t=5.1, \mathrm{df}=2, p=0.036)$ transcript levels along with decreased Ambra mRNA levels (72 hpi, $t=4.9, \mathrm{df}=2, p=0.039 ; 1 \mathrm{wpi}, t=$ $8.2, \mathrm{df}=2, p=0.014)$ at $72 \mathrm{~h}$ and week 1 after SCI, respectively. Beclin 1 transcript levels remained unchanged $(t=3,7, \mathrm{df}=2$, $p=0.065$ ) at week 1 after SCI (Fig. $1 A$ ). We then determined the chronic effects of SCI on the ERSR and autophagy mRNA levels. qPCR data showed significant upregulation in transcript levels of Atf4 $(t=8.5, \mathrm{df}=3, p=0.003)$ and Chop $(t=7.2, \mathrm{df}=3, p=$ $0.006)$ in contrast to Gadd34 $(t=14.5, \mathrm{df}=3, p=0.001)$ and $X b p 1(t=15.9, \mathrm{df}=3, p=0.001)$ (Fig. $1 B)$ and correlated with significant increase in Atg5 $(t=5.9, \mathrm{df}=2, p=0.028)$ and Beclin 1 mRNA levels $(t=4.6, \mathrm{df}=2, p=0.044)$ (Fig. $1 A)$ at 6 weeks after SCI (one-sample $t$ test vs sham). These results are consistent with an earlier study showing that Perk-Atf4-Chop pathway is essential for stress-induced autophagy gene expression ( $B$ 'chir et al., 2013). To determine autophagic flux, protein lysates derived 

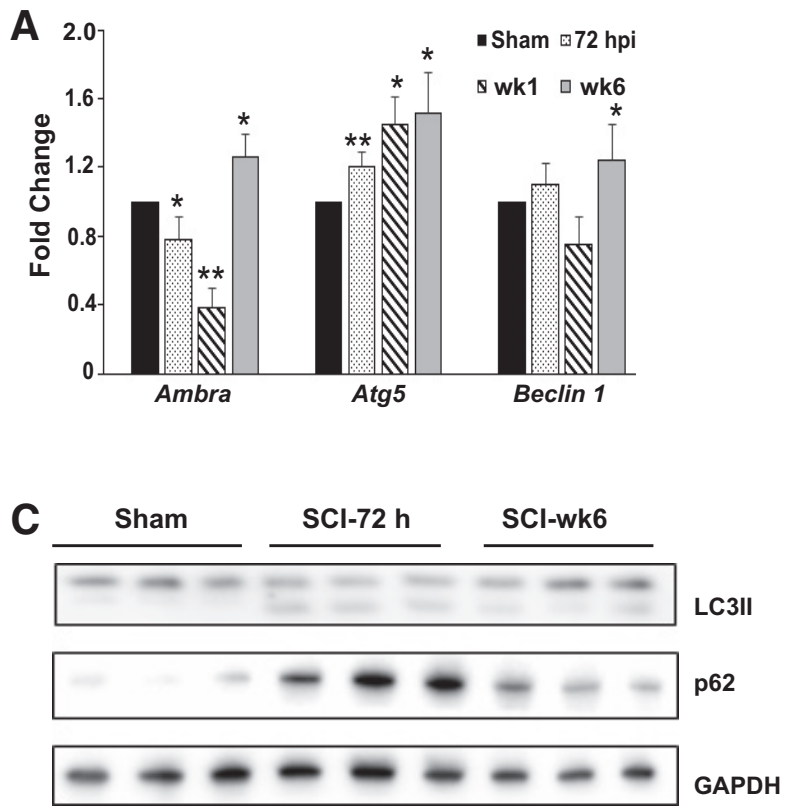

B

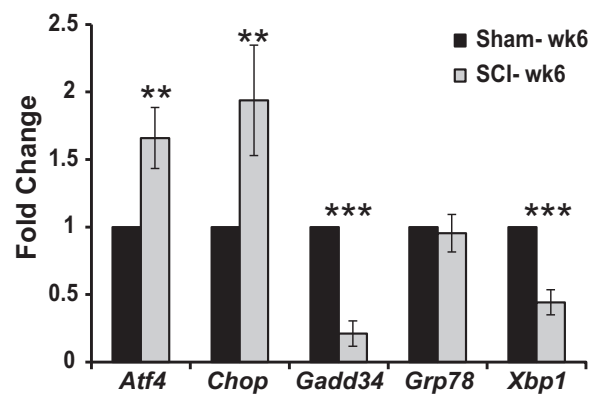

D

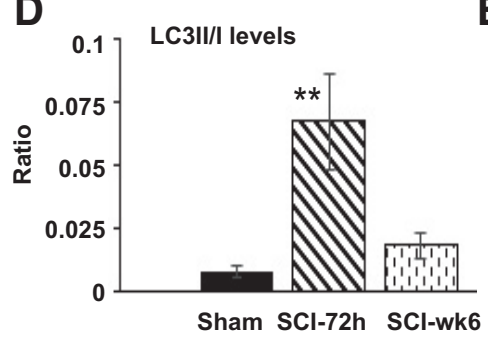

E

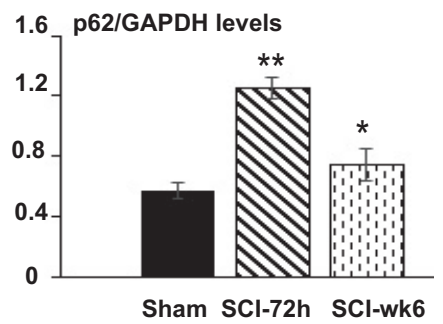

Figure 1. Increased ERSR and autophagy markers after SCl. Total RNA was isolated from injury epicenter of contused T9 WT mice at $72 \mathrm{~h}$, week 1 (wk1) ( $\boldsymbol{A}$ ) and week 6 (wk6; $\boldsymbol{B}$ ) and analyzed using qPCR for key ERSR and autophagy mRNAs as indicated. Protein lysates derived from sham and injury epicenter of contused T9 WT mice at $72 \mathrm{~h}$ and 6 weeks show increased protein levels of $L(3 B$ II and $p 62$ on a representative Western blot $(\boldsymbol{C})$ and quantitation $(\boldsymbol{D}, \boldsymbol{E})$. Data are mean $\pm \mathrm{SD}\left(n=3\right.$ or 4/group). ${ }^{*} p<0.05,{ }^{* *} p<0.01,{ }^{* * *} p<0.001$.

from injury epicenter at various time intervals after SCI were analyzed. Western blot demonstrated elevated levels of lipidated LC3BII at $72 \mathrm{~h}$ after SCI $(t=0.95 ; p=0.002)$ (Fig. $1 C, D)$, which identifies autophagosomes and is an indicator of ongoing autophagy (Zhang et al., 2013). However, the simultaneous presence of elevated levels of p62/SQSTM1 (an autophagic adapter that acts as a cargo receptor for degradation) (72 hpi, $t=0.04$, $p=0.000 ; 6 \mathrm{wpi}, t=5.1, \mathrm{df}=2, p=0.036$ ) (Fig. $1 C-E$ ) at acute and chronic time intervals after SCI, suggested a block in autophagosome degradation. Collectively, these data suggest that, even though SCI results in enhanced ERSR and autophagy gene expression pathway, autophagosome degradation is blocked and thus autophagy flux is dysregulated. These data are consistent with earlier studies (Tanabe et al., 2011; Chen et al., 2013; S. Liu et al., 2015).

\section{Contused spinal cord OLs are enriched in key autophagic markers}

Recent studies have immunohistochemically demonstrated the presence of autophagy markers in neurons, astrocytes, and OLs after SCI (Kanno et al., 2009, 2011; Hu et al., 2010; S. Liu et al., 2015). To confirm autophagy in OLs, longitudinal spinal cord sections from T9-contused WT mice demonstrated colocalization of p62 with Olig2 (Fig. $2 A$, bottom) at $72 \mathrm{~h}$ after SCI. Sham mice were analyzed in parallel (Fig. 2A, top). Quantitative analysis showed a significant increase in colocalization of p62 with Olig2 after SCI ( $t=5.6$, df $=4, p=0.005$ ) (Fig. $2 B)$ and is consistent with our Western blot data (Figure $1 C$ ) and previously published studies. Elevated levels of p62 in OPCs/OLs suggest dysregulated autophagic flux. Previous studies have shown that, after SCI, adult OPCs proliferate in the acutely injured spinal cord and their progeny differentiates into new OLs that remyelinate spared axons (Hesp et al., 2015). To determine whether autophagy has a role in myelin function after SCI, myelin was isolated by sucrose floatation from sham and contused spinal cord of WT mice at $8 \mathrm{~d}$ after SCI. Western blot of crude (C) and purified $(\mathrm{P})$ myelin fractions from sham mice show enrichment in MBP (Fig. 2C) levels in contrast to GFAP levels. Purified myelin fractions from contused SCI mice show degraded myelin bands suggesting myelin loss after SCI. Interestingly, the protein levels of key autophagy markers, including LC3B, ATG5, and BECLIN 1, are enriched in purified myelin fractions of contused $8 \mathrm{~d}$ after SCI samples in contrast to shams. These data show that SCI-induced myelin loss correlates with enrichment of key autophagy markers, suggesting the possibility that autophagy is active in damaged myelin clearance and/or remyelination after SCI.

\section{Pharmacological blockade of ER stress-induced autophagy in OPCs improves survival}

The ER stress-inducing drug Tm blocks protein glycosylation and kills $60 \%$ of mOPCs in cell culture by $24 \mathrm{~h}$. To understand the cell-autonomous impact of modulating autophagy in response to ER stress, mOPCs were treated with Tm in presence of the autophagy inhibitor spautin 1 (Fig. 3) or activator rapamycin (Fig. 4). Spautin 1 blocks Tm-induced autophagy as shown by the decrease in the $14 \mathrm{kDa}$ lipidated LC3BII protein $(F=181.2, \mathrm{df}=$ $2,6, p=000 ; t=0.29, p=0.000 ; t=0.29, p=0.000)($ Fig. $3 B, D)$. There was a significant increase in cell viability of mOPCs with spautin $1(F=1168.4, \mathrm{df}=11,24, p=0.000)$. Spautin 1 partially protects against Tm-induced cell death at indicated concentrations $(2.5 \mu \mathrm{M}, t=8.6, p=0.000 ; 5 \mu \mathrm{M}, t=15.4, p=0.000 ; 7.5$ $\mu \mathrm{M}, t=21.8, p=0.000 ; 10 \mu \mathrm{M}, t=26.3, p=0.000)($ Fig. $3 A$ ), which correlates with the decrease in protein levels of CC3 $(t=$ $0.08, p=0.000$ ) (Fig. 3C,E). Rapamycin, which induces autophagy, increased lipidated $14 \mathrm{kDa}$ LC3BII protein levels $(t=$ $0.35, p=0.004$ ) (Fig. $4 B, C$ ) but did not affect Tm-induced cell death (Fig. 4A). However, rapamycin alone significantly decreased cell viability of mOPCs at $2.5 \mu \mathrm{M}(t=7.3, p=0.000)$, $5 \mu \mathrm{M}(t=16.3, p=0.000), 7.5 \mu \mathrm{M}(t=23.2, p=0.000)$, and 10 $\mu \mathrm{M}(t=26.8, p=0.000)$. This suggests that inhibition of mTOR activity is likely detrimental in these cells, consistent with previous data demonstrating the importance of mTOR for OL health 

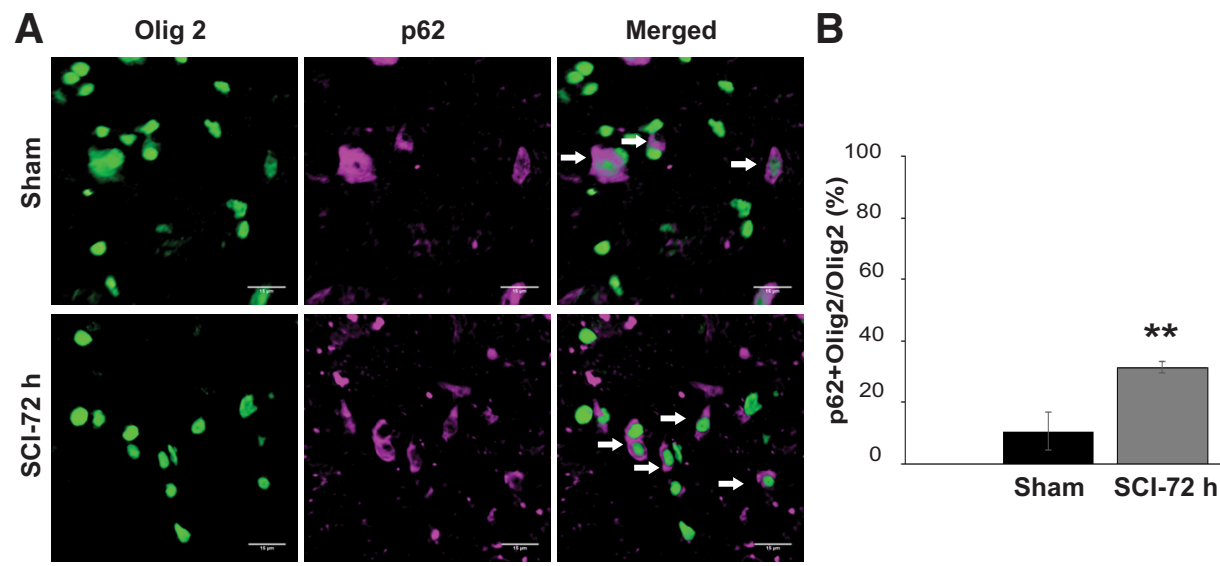

C
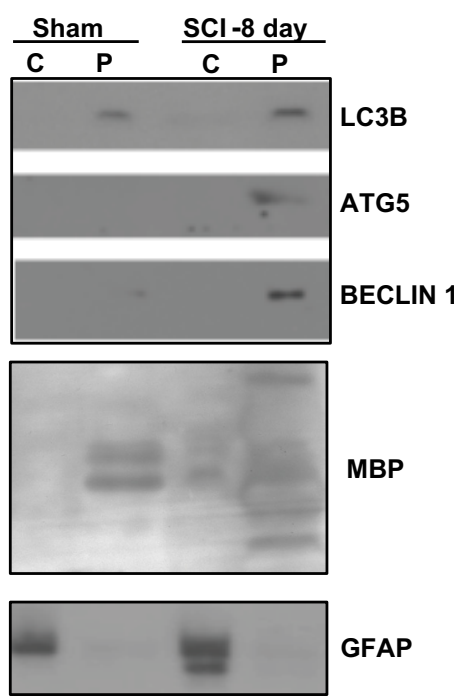

MBP

Myelin Fractions

Figure 2. Impaired autophagic flux in OLs and in purified myelin fractions after SCI. Representative confocal images of longitudinal spinal cord sections (20 $\mu \mathrm{m})$ of sham and T9-contused WT mice analyzed for p62 (magenta) and 0lig 2 (green) at $72 \mathrm{~h}$ after SCI (A) and quantitation (B). Arrows indicate individual colococalized cells. Scale bar, $15 \mu \mathrm{m}$. Data are mean \pm SD $\left(n=3\right.$ or 4). ${ }^{* *} p<$ 0.01. C, Myelin fractions were isolated by sucrose floatation from sham and contused spinal cord of WT mice at $8 \mathrm{~d}$ after SCI. (rude (C) and purified (P) fractions were analyzed for autophagy markers, MBP and GFAP as indicated on a representative Western blot.
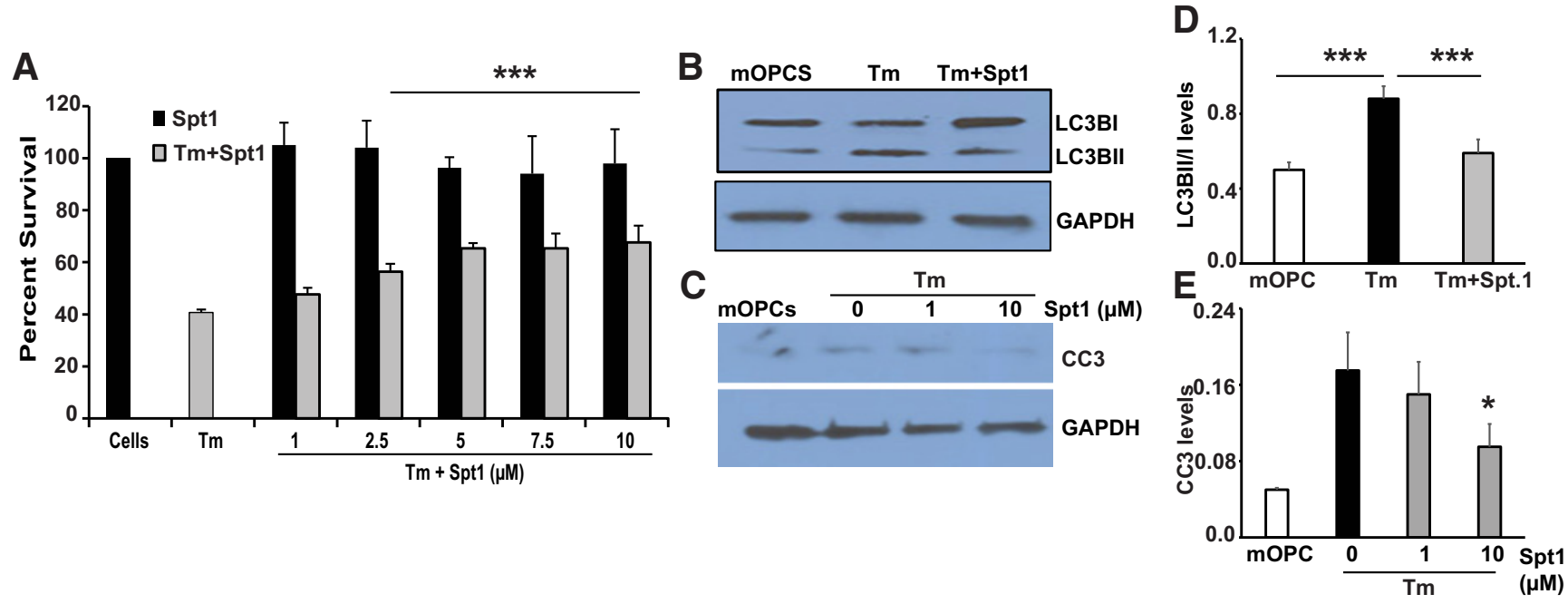

Figure 3. Effect of spautin 1 on $\mathrm{mOPCs}$ in the presence of ER stress. $A$, MTT assay shows increased viability of mOPCs treated with spautin 1 (Spt 1 ) in the presence of Tm. $\boldsymbol{B}, C$, Protein lysates from WT mOPCs treated with Spt 1 show a decrease in $\mathrm{LC} 3 \mathrm{~B} I \mathrm{l}$ and $\mathrm{CC} 3$ protein levels in the presence of Tm on a representative Western blot. $\boldsymbol{D}, \boldsymbol{E}$, Quantification of the Western blots as in $\boldsymbol{B}, \boldsymbol{C}$. Data are mean \pm SD $\left(n=4\right.$ experiments). ${ }^{*} p<0.05,{ }^{* * *} p<0.001$.

(Narayanan et al., 2009; Tyler et al., 2009). These data indicate that pharmacological inhibition of autophagy is beneficial to acute OPC survival in the context of the ERSR.

Pharmacological modulation of autophagy after thoracic SCI does not improve locomotor recovery

To determine whether we could effectively inhibit or enhance autophagy in vivo, we injected spautin 1 or rapamycin, respectively, acutely after traumatic SCI. C57BL/6 female mice received a moderate T9-SCI and within $1 \mathrm{~h}$ after SCI received an intraperitoneal injection of vehicle, spautin $1(1 \mathrm{mg} / \mathrm{kg})$, or rapamycin (1 $\mathrm{mg} / \mathrm{kg}$ ) based on earlier published work (Sekiguchi et al., 2012; Chen et al., 2013). Twenty-four hours later, the injury epicenter was isolated and probed for the lipidation of cleaved LC3BI to LC3BII (Fig. $5 A$, top, $B, D$, top, $E$ ). Blots were stripped and re- probed for phosphorylated (pS6) and total (S6) kinase whose inactivation is autophagy-mediated (Fig. $5 A$, bottom, $C, D$, bottom, $F$ ). Western blots showed that spautin 1 decreased LC3BII levels $(t=14.3$, df $=6, p=0.000)$ as expected for autophagy inhibition but surprisingly increased pS6/S6 ratios $(t=10.0, \mathrm{df}=$ $6, p=0.000)$, whereas the autophagy activator rapamycin did the reverse (LC3BII: $t=3.5$, df $=5, p=0.018$; pS6: $t=3.8, \mathrm{df}=5$, $p=0.012)$. These data indicate that both spautin 1 and rapamycin were able to penetrate the blood-brain barrier after SCI and were pharmacologically active in vivo.

To understand the functional consequences of blocking and enhancing autophagy after SCI, we next evaluated the effects of rapamycin and spautin 1 on locomotor recovery after SCI. Comparison of the BMS scores between moderately contused WT ( $n=9$ /group) mice injected with vehicle and drug (rapamycin or 


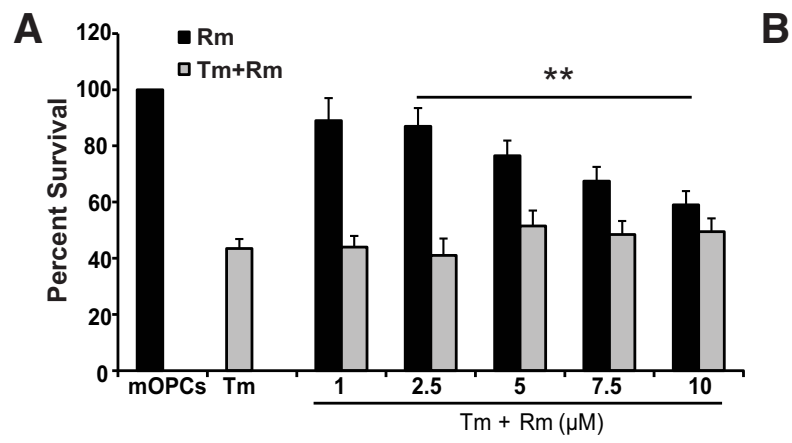

B

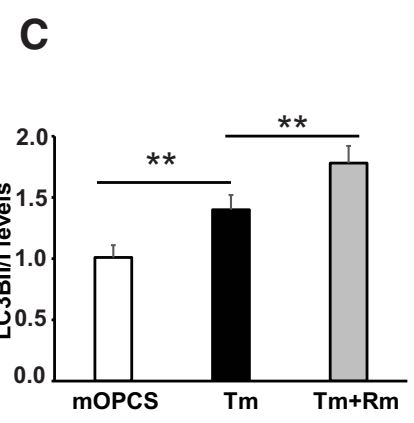

Figure 4. Effect of rapamycin on $\mathrm{mOPCs}$ exposed to ER stress. $A$, MTT assay shows significant decrease in viability with rapamycin (Rm) alone but no difference in viability of mOPCs treated with Rm in the presence of Tm. $\boldsymbol{B}$, Protein lysates of WT mOPCs treated with Rm show an increase in LC3BII levels in the presence of Tm on a representative Western blot. C, Quantification of the Western blots as in $\boldsymbol{B}$. Data are mean \pm SD $\left(n=4\right.$ experiments). ${ }^{* *} p<0.01$.

A
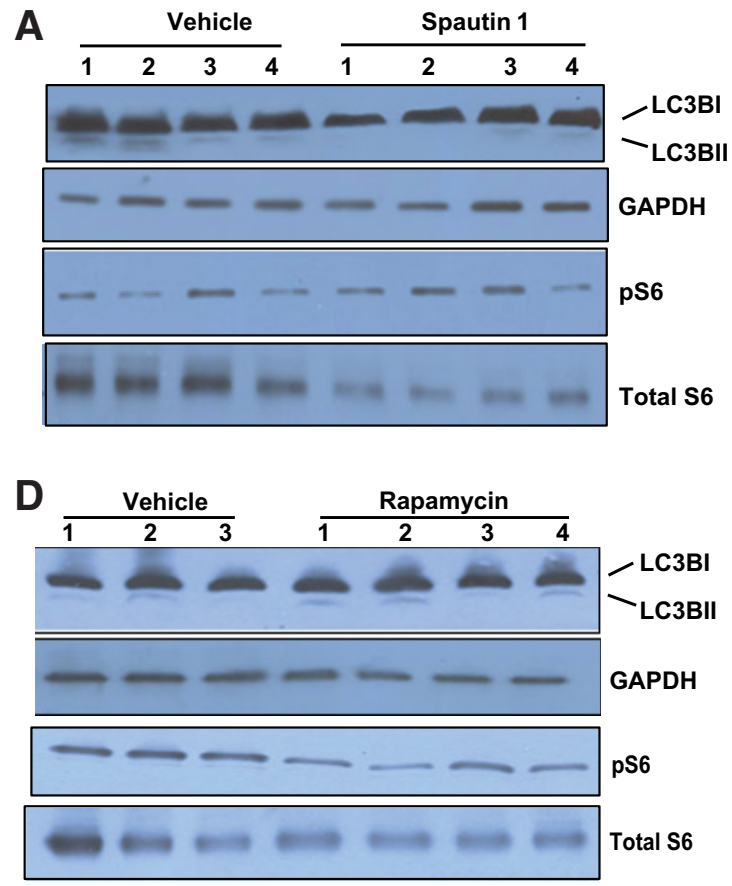

B

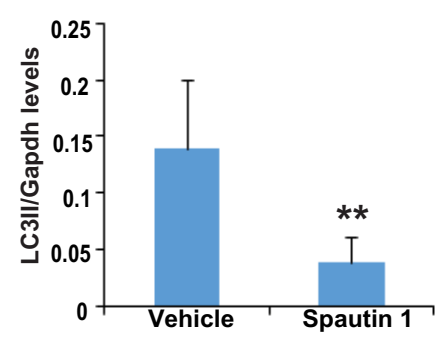

E

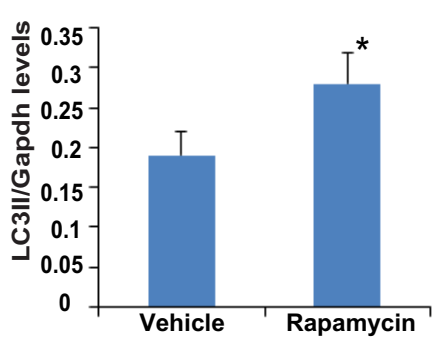

C

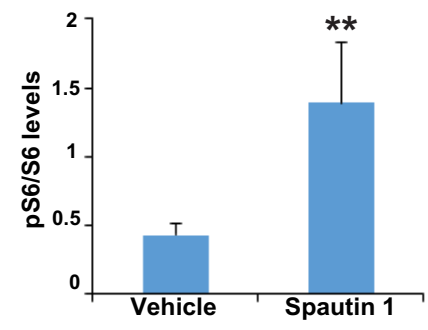

$\mathbf{F}$

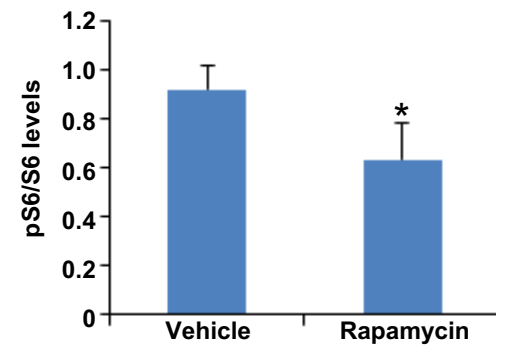

Figure 5. Spautin 1 and rapamycin modulate autophagy after SCI. Protein lysates from injury epicenter of spautin 1-treated contused T9 WT mice at $24 \mathrm{~h}$ show decrease in $L C 3 B \mathrm{BI}$ levels $(\boldsymbol{A}, \boldsymbol{B})$ and increase in pS6 levels $(\boldsymbol{A}, \boldsymbol{C})$. Rapamycin-treated protein lysates show an increase in LC3BII levels $(\boldsymbol{D}, \boldsymbol{E})$ and decrease in pS6 levels $(\boldsymbol{D}, \boldsymbol{F})$. Data are mean \pm SD $(n=3$ or 4$) .{ }^{*} p<0.05,{ }^{* *} p<0.01$.

spautin 1) revealed no differences (Fig. 6). The average BMS scores for vehicle- and spautin 1-treated mice were $4.25 \pm 0.44$ and $4.19 \pm 0.65$ at week 1 and $5.25 \pm 0.68$ and $4.9 \pm 0.85$ at week 6 , respectively (Fig. 6A). BMS subscore data between these two groups did not show any difference in the stepping characteristics (data not shown) either. Similarly, the average BMS scores for vehicle- and rapamycin-treated mice were $3.55 \pm 0.58$ and $3.85 \pm 0.44$ at week 1 and $4.75 \pm 0.75$ and $5.01 \pm 0.99$ at week 6 , respectively (Fig. $6 B$ ). Analysis of the BMS subscore did not show any differences in the stepping characteristics between these two groups of mice (data not shown). While some studies previously reported beneficial effects of rapamycin on functional recovery after SCI in mice and rats (Sekiguchi et al., 2012; Chen et al., 2013; Tang et al., 2014), our data are consistent with $\mathrm{Hu}$ et al. (2010) who did not report any functional effects with enhancing autophagy with rapamycin and Chen et al. (2013) who did not report any functional effects with blocking autophagy with 3-methyladenine. Together, these data indicate that, given the major caveat of significant off-target effects of drugs that target autophagy (Wahl et al., 2014), the pharmacological modulation of autophagy, in either direction, after SCI does not result in enhanced locomotor recovery.

\section{Genetic deletion of Atg5 specifically in OLs enhances ERSR and lowers cell viability in vitro}

While global Atg5 deletion is embryonic lethal, tissue-specific knock-outs of autophagy genes have revealed critical roles of autophagy in tissue homeostasis in skeletal and cardiac muscle, pancreas, small intestine, immune cells, podocytes, and neural cells (Mariño et al., 2011). Here, we used OL-specific Plp-cre $e^{E R T 2+/+}$ : $\operatorname{Atg} 5^{f l / f l}$ mice to determine whether autophagy is a positive or negative regulator of OL function in SCI. To understand the cell-autonomous effects of Atg5 deletion, Plp-cre $e^{E R T 2+/+}:$ Atg $5^{f l / f l}$ mice-derived mOPCs were treated with vehicle or tamoxifen. Significant decrease in protein levels of ATG5 $(t=.51, p=.008)$ (Fig. 7A-B) was evident in tamoxifen-treated mOPCs. Experimental ER stress induced by Tm caused increased levels of p62 $(t=.99, p=.000)$ and decreased levels of LC3BII $(t=.76, p=$ 

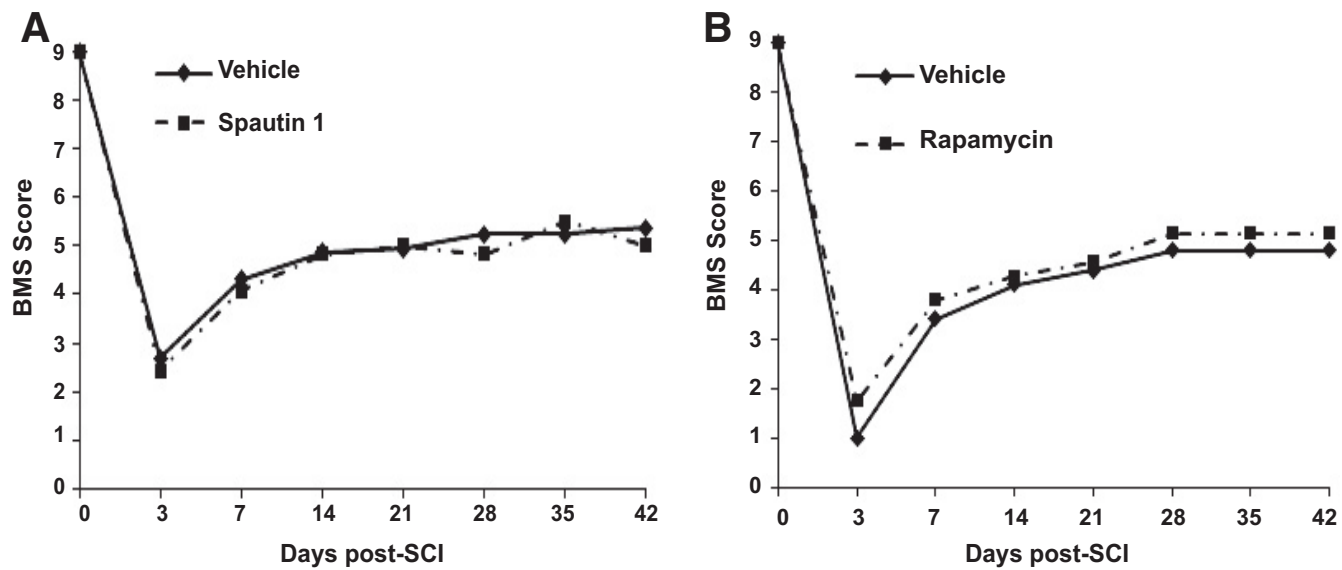

Figure 6. Pharmacological modulation of autophagy does not improve locomotor deficits. Open field BMS locomotor analyses, performed weekly for all experimental animals treated with ( $\boldsymbol{A}$ ) spautin $1,1 \mathrm{mg} / \mathrm{kg}$ and $(\boldsymbol{B})$ rapamycin, $1 \mathrm{mg} / \mathrm{kg}$, show no difference in locomotor recovery compared with vehicle-treated animals. Data are mean \pm SD ( $n=8$ or $9 / \mathrm{group}$ ).

A
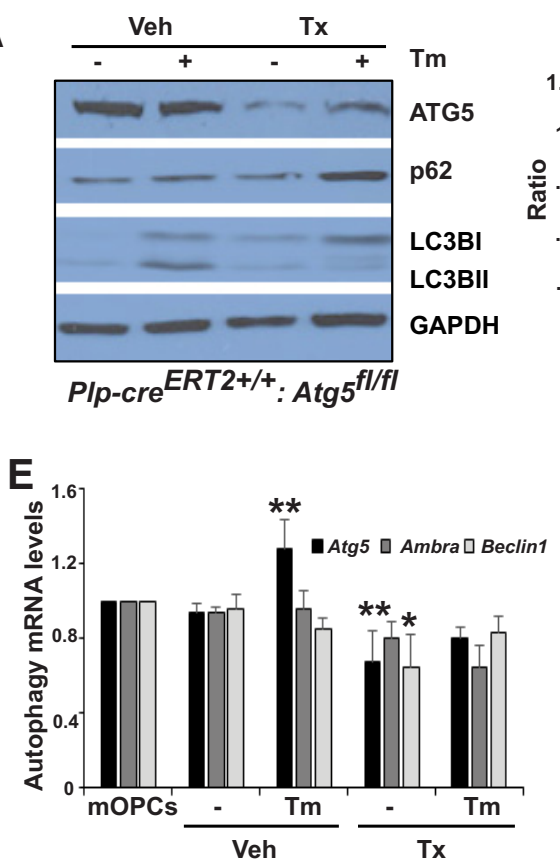

B

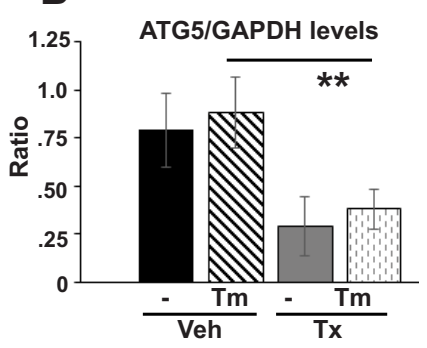

$\mathbf{F}$

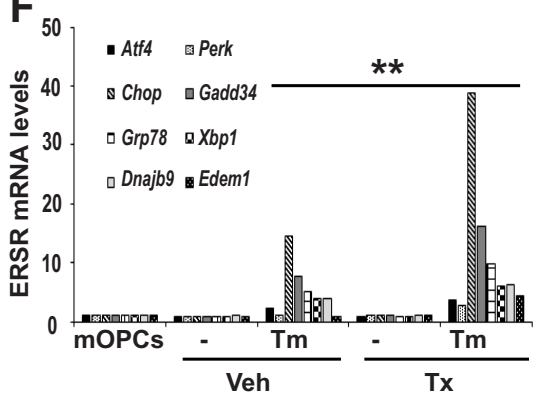

C

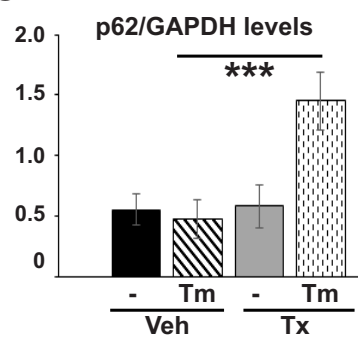

D

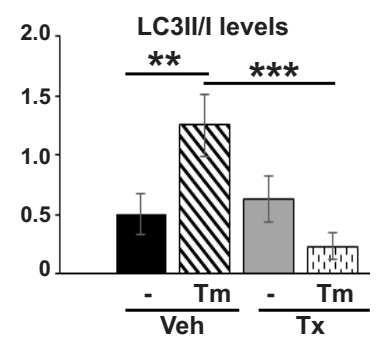

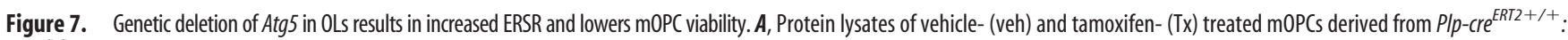
Atg $5^{f l / f l}$ mice are analyzed for ATG5, LC3BII, and p62 levels in the presence and absence of Tm. $\boldsymbol{B}$-D Quantification of the Western blots as in $\boldsymbol{A}$. $\boldsymbol{E}, \boldsymbol{F}$, Total RNA was isolated from vehicle- and Tx-treated mOPCs derived from PIp-cre ${ }^{E R T 2+/+}:$ Atg $5^{f l / f l}$ mice and analyzed for essential autophagy and ERSR markers using qPCR as indicated. G, MTT assay shows decreased viability of Tx-treated m0PCs from $P I p-c r e e^{E R T 2+/+}: A t g 5^{f l / f l}$ mice compared with vehicle-treated m0PCs in the presence of Tm and thapsigargin (Tg). Data are mean \pm SD $\left(n=4\right.$ experiments). ${ }^{*} p<0.05,{ }^{* *} p<0.01,{ }^{* * *} p<0.001$.

.003) (Fig. $7 A, C, D$ ) in tamoxifen-treated mOPCs in contrast to vehicle-treated mOPCs. A significant reduction in Atg5 $(t=30.5$, $\mathrm{df}=2, p=.001)$ and Beclin $1(t=6.3, \mathrm{df}=2, p=.024)$ mRNA levels (Figure 7E) further confirmed successful recombination efficiency. These data indicated that, under conditions of stress, autophagy was activated in ER stress-induced mOPCs. However, upstream inhibition of autophagy resulted in reduced/impaired autophagic flux in mOPCs. A significant increase in ERSR mRNA, including Xbpl $(t=31.7, \mathrm{df}=2, p=0.001)$, Atf4 $(t=$ $50.3, \mathrm{df}=2, p=0.000)$, Chop $(t=17.5, \mathrm{df}=2, p=0.003)$, Grp78 $(t=31.8, \mathrm{df}=2, p=0.001), D N j 69(t=23.2, \mathrm{df}=2, p=0.002)$, Perk $(t=7.0, \mathrm{df}=2, p=0.020)$, and Gadd34 $(t=16.7, \mathrm{df}=2$, $p=0.004)$ (Fig. $7 F)$, was evident in tamoxifen-treated mOPCs that were exposed to ER stress compared with the vehicle group. These data indicated that the ERSR was exacerbated in the pres- ence of impaired autophagic flux. Finally, MTT analysis demonstrated a significant reduction in cell viability of tamoxifentreated mOPCs in the presence of ER stress (Tm, $t=19.7, p=$ 0.000; Tg, $t=20.7, p=0.000$ ) (Fig. $7 G$ ) compared with vehicle group. Collectively, these data indicated that reduced/impaired autophagy resulted in a greater ERSR under conditions of stress and correlated with decreased survival of mOPCs.

\section{OLs-specific deletion of Atg5 limits functional recovery after thoracic SCI}

To understand the functional consequences of reduced autophagy by deleting Atg5 from OLs after SCI, Plp-cre ${ }^{E R T 2+/+}$ : Atg $5^{\text {fl } / f l}$ mice were analyzed for locomotor recovery after SCI. We first determined whether we could effectively remove Atg5 from OLs in vivo by injecting tamoxifen $(1 \mathrm{mg} / \mathrm{mice})$ to $\mathrm{Plp}$ - 

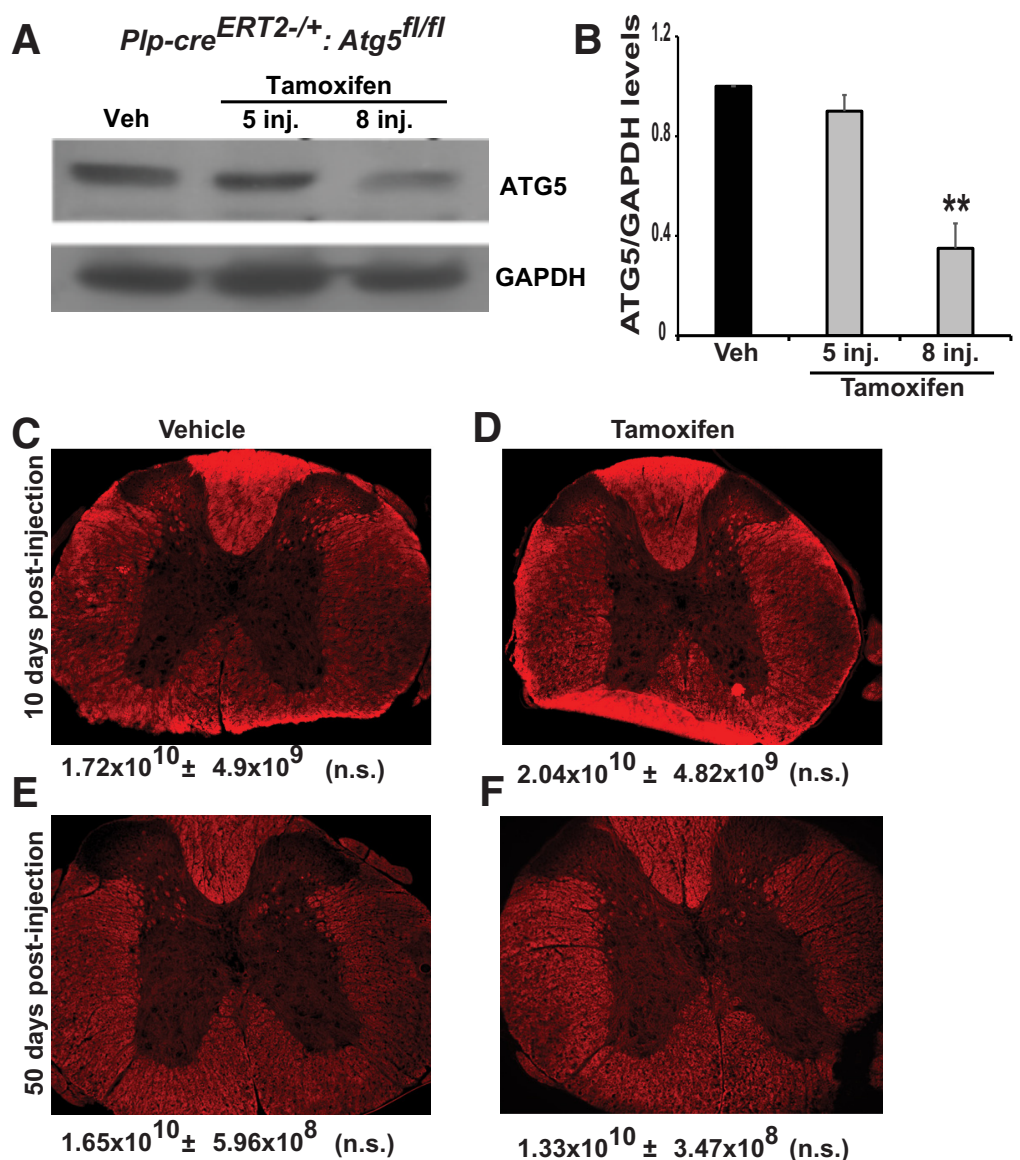

Figure 8. Specific deletion of $A \operatorname{tg} 5$ in $0 \mathrm{LS} . A$, Protein lysates from $4 \mathrm{~mm}$ section of spinal cord of vehicle- and tamoxifen-treated $P / p-c r e^{E R T 2+/+}:$ Atg $5^{f / f l}$ mice show significant reduction in ATG5 protein levels with 8 injections (inj.) of tamoxifen. B, Quantification of the Western blot as in $A$. Data are mean $\pm S D$ ( $n=3 /$ group). ${ }^{* *} p<0.01$. Fluoromyelin-stained spinal cord sections from vehicle- and tamoxifen-treated mice show no difference in average intensity values as indicated for each group at $10 \mathrm{~d}(\boldsymbol{C}, \boldsymbol{D})$ and $50 \mathrm{~d}(\boldsymbol{E}, \boldsymbol{F})$ after tamoxifen injection. Data are mean \pm SD $(n=3 /$ group) and represent arbitrary fluorescence units.

${ }^{c r} e^{E R T 2+/+}: \operatorname{Atg}^{f l / f l}$ mice $1 \times / \mathrm{d}$ for either 5 or $8 \mathrm{~d}$ (Doerflinger et al., 2003). Five days after the last injection, spinal cord derivedprotein lysates from mice with 8 injections showed a significant reduction in ATG5 protein levels $(t=23.2, \mathrm{df}=2, p=0.002)$ (Fig. $8 A, B$ ). These are whole spinal cord homogenates; and while OLs have a large fraction of total spinal cord ATG5, some remain in other cell types. Next, to determine whether tamoxifen administration altered the myelin content in the spinal cord before injury, sections from vehicle- and tamoxifen-treated mice killed at 10 and $50 \mathrm{~d}$ after injection were stained with FluoroMyelin Red. No significant difference in the staining intensity was detected between vehicle- and tamoxifen-treated mice at either time point (Fig. $8 C-F$ ). These data indicate that, while the ATG5 protein levels were significantly reduced with tamoxifen, the myelin content remained equal in both the groups before injury at both the acute and chronic time intervals after tamoxifen.

BMS analyses showed a significant reduction in functional recovery after SCI in tamoxifen-treated $P l p-c r e^{E R T 2+/+}: A \operatorname{tg} 5^{f l f l}$ mice $(F=$ 55.4 , $\mathrm{df}=1,91, p=0.000$ ) compared with vehicle-treated mice (Fig. $9 A$ ). The significant differences were observed at $28 \mathrm{~d}$ after SCI and sustained through $42 \mathrm{~d}$ ( $28 \mathrm{dpi}, t=0.67, \mathrm{df}=14, p=0.019 ; 35 \mathrm{dpi}, t=$ $1.1, \mathrm{df}=14, p=0.000 ; 42 \mathrm{dpi}, t=1.1, \mathrm{df}=14, p=0.000)$ in tamoxifentreated $P l p-c r e^{E R T 2+/+}:$ Atg $5^{f l / f l}$ mice. Impact force and displacement of the contusive injuries were not significantly different between groups (data not shown). To determine the possible mechanisms responsible for this reduced locomotor recovery in tamoxifen- treated mice, the spinal cords were isolated at 6 weeks after SCI and analyzed for SWM. Tamoxifen-treated $\mathrm{Plp}-\mathrm{cre} \mathrm{ERT2+/+}^{\mathrm{E}}$ : $\operatorname{Atg}^{f l / f l}$ mice showed significantly less SWM $(15.73 \% ; t=7.0$, df $=14, p=$ 0.000 ) (Fig. 9C,D) compared with vehicletreated mice $(22.52 \%)$ (Fig. 9B,D). These data suggest that increased white matter loss contributes to functional decline in mice with reduced autophagy. Collectively, our findings indicate that autophagy is a cytoprotective pathway in OLs that is required for locomotor improvement after thoracic SCI.

\section{Loss of Atg5 in OLs is detrimental to OPC/OL health after SCI}

Autophagy impairment (with Atg5 deletion) in OPCs/OLs results in greater locomotor deficits and myelin loss after SCI. To examine whether decrease in locomotor recovery in mice is indeed mediated via defects in OPCs/OLs, vehicle- or tamoxifen-treated Plp-cre ${ }^{E R T 2+/+}: A \operatorname{tg} 5^{f l / f l}$ mice were subjected to SCI at T9. Injury epicenters were collected at $72 \mathrm{~h}$ after SCI, and longitudinal sections were immunostained. Tamoxifen-treated mice demonstrated higher numbers of $\mathrm{p} 62^{+} / \mathrm{Olig} 2^{+}$ cells $(t=6.3, \mathrm{df}=5, p=0.001)$ compared with vehicle-treated group, indicating decreased autophagic flux in OPCs/OLs (Fig. 10A-C). Reduction in $\operatorname{PDGFR} \alpha^{+}$/ Olig2 ${ }^{+}$costained cells in tamoxifentreated Plp-cre $e^{E R T 2+/+}$ :Atg $5^{f l / f l}$ mice $(t=$ 2.6, $\mathrm{df}=5, p=0.049)$ indicated reduced OPC numbers marked by PDGFR $\alpha$ (Fig. $10 D-F)$. Consistent with this, there was a significant reduction in $\mathrm{Ki}^{+} 7^{+} / \mathrm{Olig}{ }^{+}$cells in the tamoxifen-treated group $(13.64 \% ; t=$ $2.9, \mathrm{df}=5, p=0.034$ ) (data not shown), indicating less proliferation. Lower numbers of CNPase ${ }^{+} /$Olig $2^{+}$cells $(t=3.9, \mathrm{df}=5$, $p=0.012$ ) (Figure $10 G-I$ ) in tamoxifen-treated $P l p-c r e^{E R T 2+/+}$ : $\operatorname{Atg} 5^{f l f l}$ mice indicated that differentiation is also decreased, an effect that may result from reduced OPC numbers. Finally, an increase in the numbers of $\mathrm{CC}^{+} / \mathrm{APC}^{+}(t=2.8, \mathrm{df}=5, p=$ 0.040) (Fig. 10J-L) and $\mathrm{CHOP}^{+} / \mathrm{Olig}^{+}(t=4.8, \mathrm{df}=5, p=$ $0.005)$ (Fig. $10 M-O$ ) cells in tamoxifen-treated $P l p-c r e^{E R T 2+/+}$ : $A \operatorname{tg} 5^{f l / f l}$ mice indicated more apoptosis and ER stress in OPC/OLs. Collectively, these data demonstrate that autophagy is involved in proliferation and differentiation of OPCs/OLs after SCI and strongly supports a critical role of autophagy in OLs during functional recovery after SCI.

\section{Discussion}

Impaired autophagic flux is involved in the pathogenesis of numerous neurodegenerative diseases, including Alzheimer's disease, Parkinson's disease, Huntington's disease, amyotrophic lateral sclerosis (Williams et al., 2006; Rubinsztein et al., 2007), and neurotrauma, including SCI (Chen et al., 2013; S. Liu et al., 2015). Although mechanisms of autophagy are documented in neurons (S. Liu et al., 2015) after SCI and in astrocytic differentiation (Wang et al., 2014), its functional role in OPCs/OLs is unknown. The key findings presented here demonstrate that spe- 

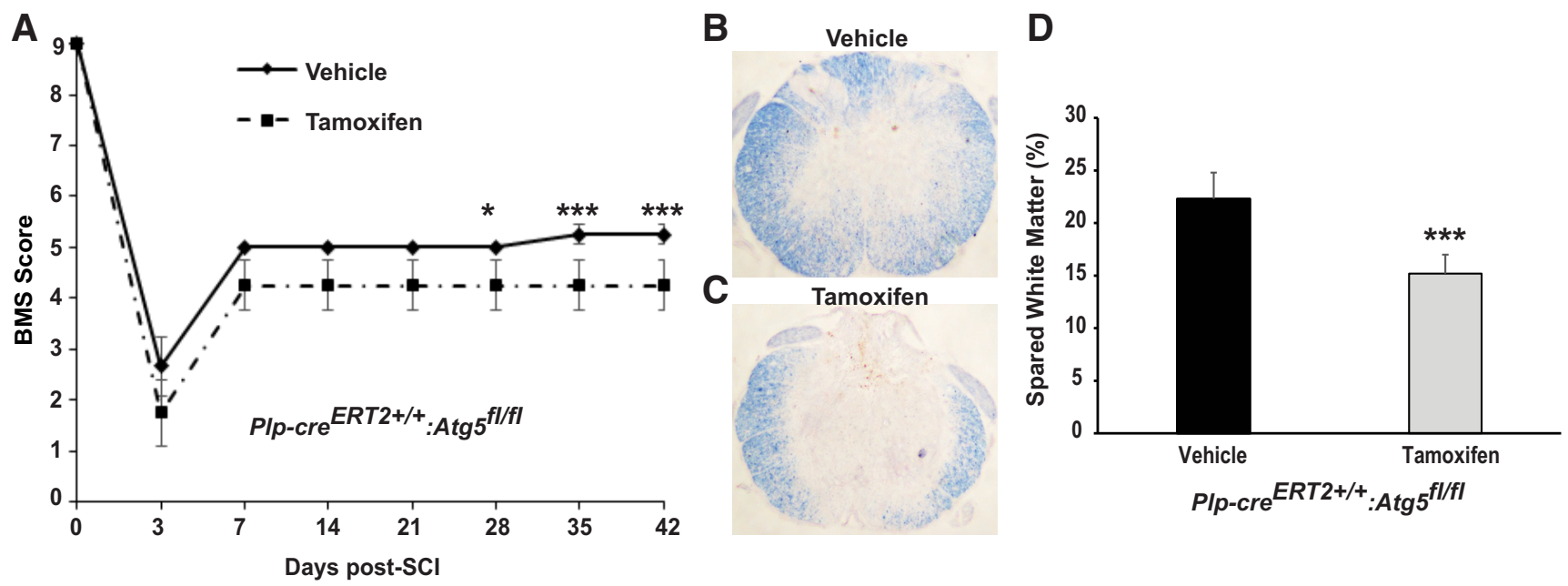

Figure 9. Genetic deletion of Atg 5 in $0 \mathrm{Ls}$ limits locomotor functional recovery after SCl. A, Open field BMS locomotor analyses performed weekly for vehicle- and tamoxifen-treated PIp-cre ${ }^{E R T 2+/+}$ :

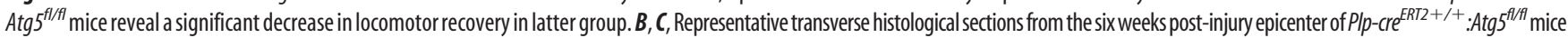
treated with $(\boldsymbol{B})$ vehicle and $(\boldsymbol{C}$ ) tamoxifen were stained with Eriochrome cyanine to identify myelin. $\boldsymbol{D}$, Quantitative analysis of Eriochrome cyanine-stained sections of tamoxifen-treated mice shows a significant reduction of $6.8 \pm 1.3 \%$ in spared white matter compared with vehicle-treated mice. Data are mean $\pm S D(n=7 /$ group $) .{ }^{*} p<0.05,{ }^{* * *} p<0.001$.

cific deletion of autophagy in OLs is detrimental to OPC/OLs function after thoracic contusive SCI and results in greater locomotor deficits and myelin loss.

The conditional deletion of Atg5 in OLs before SCI affords specific information about the role of autophagy in OL survival and their role in functional recovery. Acute in vitro data with WT mOPCs suggested that inhibition of autophagy was protective against ER stress-induced cytotoxicity. That genetic deletion of Atg5 in OLs resulted in less autophagy and reduced cell viability in response to ER stress and directly correlated with poorer functional outcome after SCI and reduced white matter sparing is in contrast with that interpretation. The loss of OLs could reflect a role for autophagy in either acute OL protection or impaired functional maintenance. While developmentally, Atg5 (and hence autophagy) is essential for myelination (A.N.B., S.R.W., unpublished observations), its induced deletion in adult mice does not affect spinal cord myelin integrity at 10 or $50 \mathrm{~d}$ after loss (Fig. 8). This likely results from subsequent proliferation and maturation of OPCs in which Atg5 is not lost. However, after SCI, Atg5-deficient OLs exhibit reduced proliferation, differentiation, and an increase in apoptosis and ER stress due to reduced autophagic flux. Supporting this, several studies have implicated autophagy in the maturation of other lineages, including neurons and astrocytes (Vázquez et al., 2012; Lv et al., 2014; Wang et al., 2014; Jang et al., 2015). The progression of OPCs to OLs includes many potential stresses, robust upregulation of transcription/ translation, drastic changes in morphology, and an eventual culling of many OLs that have not associated with axons (Miller, 2002; Emery, 2010; Simons and Nave, 2016). However, thoracic contusive SCI is primarily a white matter injury with SWM the single variable that best correlates with the extent of functional recovery (Basso et al., 2006), and neuronal loss does not contribute significantly to functional deficit with mid-thoracic SCI (Magnuson et al., 2005). Thus, reduced OPC and OL protection are the likely primary event driving the detrimental functional recovery from SCI after deletion of Atg5 from OLs and provide strong evidence that autophagy is critical in many aspects of OL function and health.
Autophagy is a central regulator of stress responses (Kroemer et al., 2010). Because of their considerable need to secrete vast amounts of myelin proteins and lipids, OLs are subject to severe ER, oxidative, and proteasomal stress (D'Antonio et al., 2009; Lin and Popko, 2009) that is counteracted by robust adaptive responses. The fact that Atg5 deletion led to enhanced ERSR in mOPCs in response to ER stress indicates a critical regulation of ER stress by autophagy in OLs. Supporting this, larger ER and enhanced ERSR were observed in plasma cells with deleted Atg5 (Pengo et al., 2013). Further, our previous studies showed that genetic or pharmacological block of the homeostatic arm ERSR in OPCs/OLs correlated with improved locomotor recovery after moderate SCI (Saraswat Ohri et al., 2011, 2013).

Previous studies showed improvement in hindlimb locomotion by enhancing autophagy with pharmacologically with rapamycin (Sekiguchi et al., 2012; Chen et al., 2013; Tang et al., 2014). In contrast, another study demonstrated improved locomotion with pharmacological inhibition of autophagy with ATP (Hu et al., 2010). Other SCI studies showed no effect in functional recovery with 3-methyladenine, which blocks autophagy (Chen et al., 2013; Tang et al., 2014). The pharmacological and genetic studies undertaken here were intended to clarify this functional discrepancy and understand the role of autophagy, especially in OL function. The fact that spautin 1 and rapamycin had opposite effects on levels of LC3BII and pS6 at the lesion epicenter after SCI (Fig. 5) showed their ability to penetrate the spinal cord tissue in vivo and appropriately influence autophagy. Consistent with this, elevation of lipidated LC3BII as a marker of autophagy induction (Kabeya et al., 2000) has been reported in many models of CNS disease, including permanent focal cerebral ischemia (Wen et al., 2008), experimental intracerebral hemorrhage (He et al., 2008), and SCI (Chen et al., 2013) in adult rats and experimental TBI in mice (Lai et al., 2008;C. L. Liu et al., 2008). Here, neither spautin 1 nor rapamycin improved the locomotor deficits after thoracic SCI. The possible reasons for the lack of functional improvements after SCI with rapamycin in this study compared with the previously published work are multiple. SCI induces a complex pathophysiology, including inflammation, hypoxia, excitotoxicity, disruption of the blood-brain barrier, ischemia, and 
A

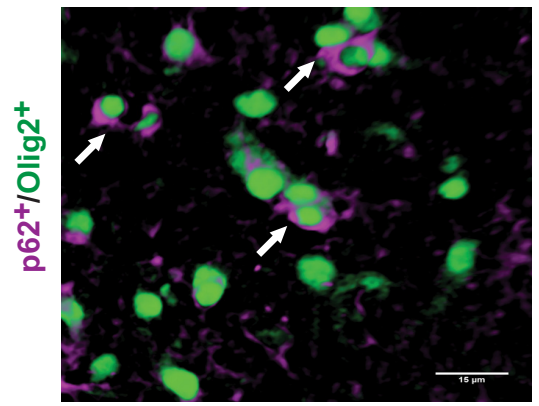

D

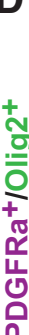

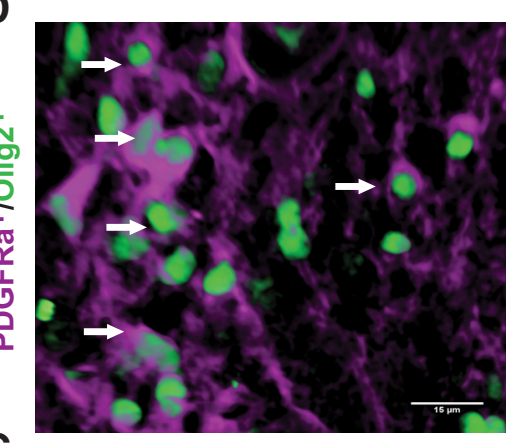

G

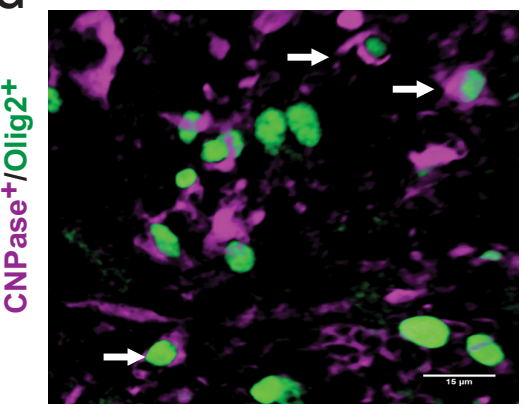

J
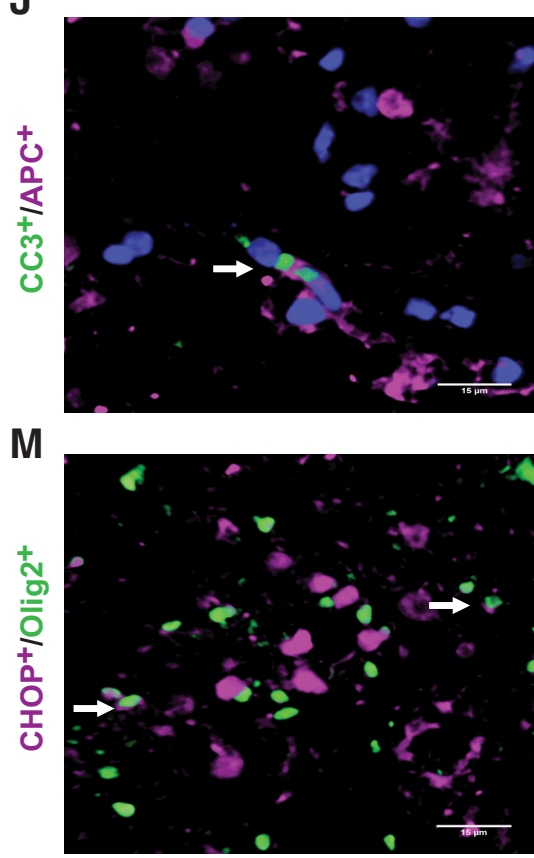

B

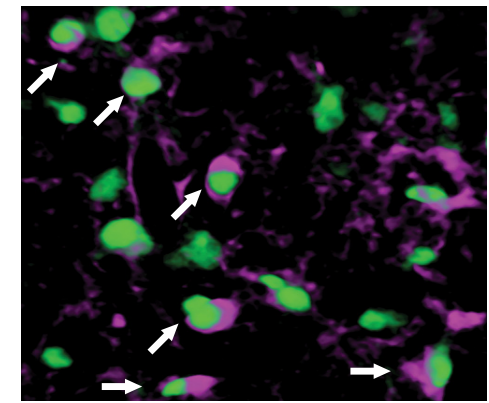

E

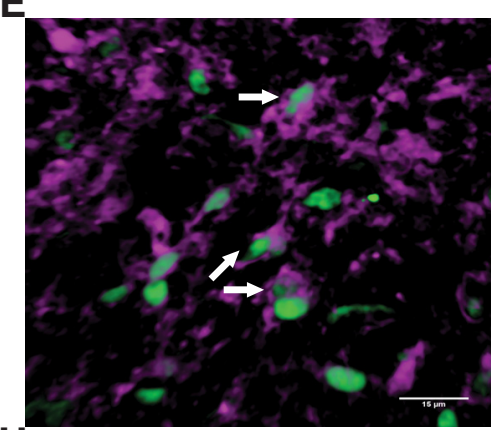

$\mathrm{H}$

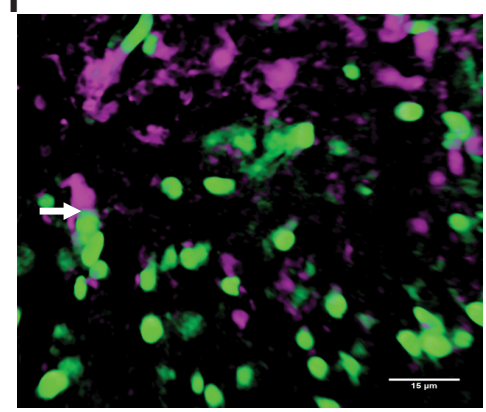

K

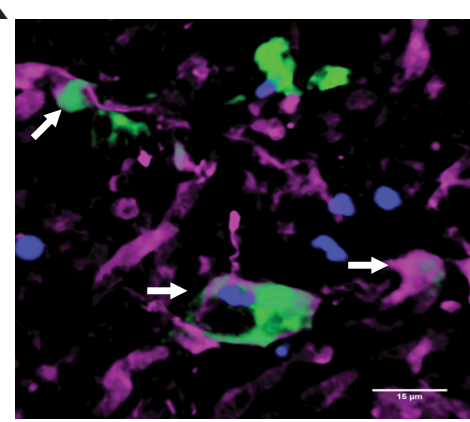

N

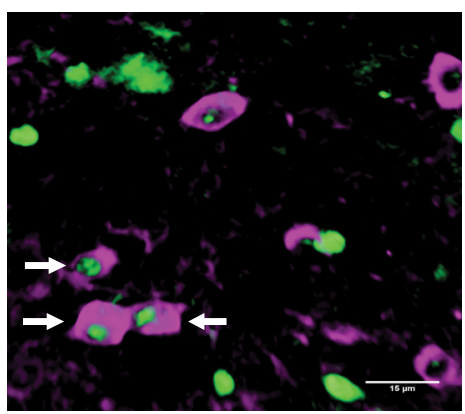

C

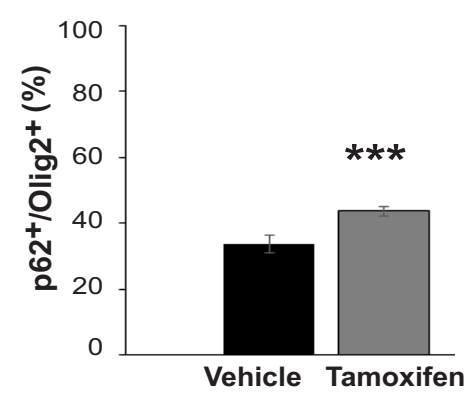

F
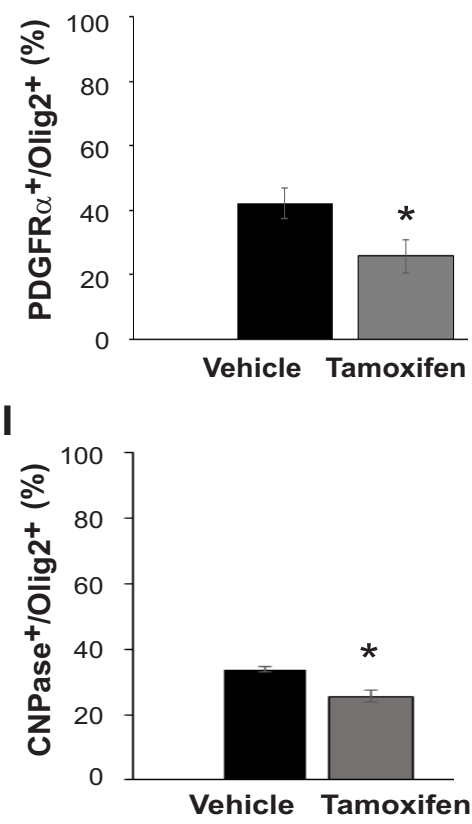

$\mathbf{L}$

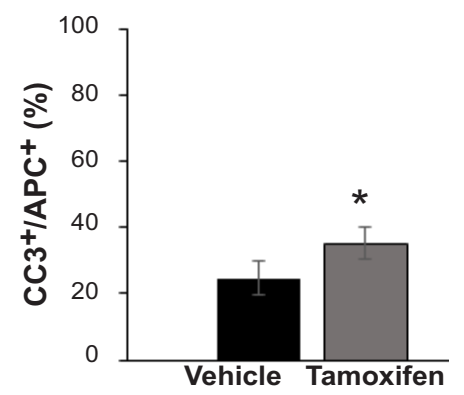

O

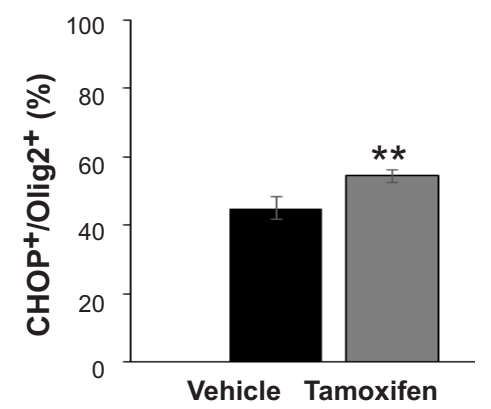

Figure 10. Decreased autophagy flux and survival of OPC/OLs after SCI with genetic deletion of Atg5. Six $20 \mu$ m longitudinal sections (every fifth section through each cord) were immunostained and imaged under identical conditions. Representative confocal images of vehicle-treated $(\boldsymbol{A}, \boldsymbol{D}, \boldsymbol{G}, \boldsymbol{J}, \boldsymbol{M})$ and tamoxifen-treated $(\boldsymbol{B}, \boldsymbol{E}, \boldsymbol{H}, \boldsymbol{K}, \boldsymbol{N})$ Plp-cre ${ }^{E R T 2+/+}:$ Atg $5^{f / f f l}$ mice show colocalization and

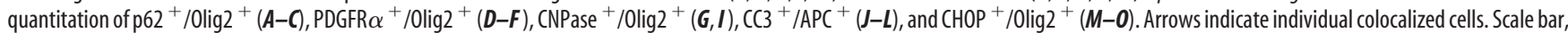
$15 \mu \mathrm{m}$. Data are mean $\pm \mathrm{SD}(n=3$ or 4$) .{ }^{*} p<0.05,{ }^{* *} p<0.01,{ }^{* * *} p<0.001$. 
demyelination (Hagg and Oudega, 2006; Rowland et al., 2008) and affects multiple cell types. When interpreting pharmacological gain and loss of autophagy function data after CNS injury, one must recognize that all cell types are potentially equally affected. Current data show a clear role for autophagy in OL protection in vitro. Additionally, autophagy has been implicated in cellular protective responses in both neurons (Cai et al., 2015; Radad et al., 2015; Yin et al., 2017) and astrocytes (Cao et al., 2016; Pla et al., 2016; Shen et al., 2016) and also plays a major role in microglial activation (Su et al., 2016) and more globally in inflammation (Zhong et al., 2016; Messer, 2017). Neuroprotection and inflammation are also affected by other signaling pathways regulated by mTOR (Grummisch et al., 2016; Shi et al., 2017). Many of the drugs commonly used to control autophagy target signaling proteins upstream of the autophagy pathway. For instance, spautin 1 inhibits Type III P13 kinase, which is downstream of mTOR in the autophagy pathway (J. Liu et al., 2011). Unexpectedly, spautin 1 significantly modulated S6 phosphorylation levels, indicating that it is also a nonspecific drug and affects mTOR signaling. The pharmacological target of autophagy is mTOR, which is involved in multiple aspects of OL development and maturation (Tyler et al., 2009; Gomez-Sanchez et al., 2015) and is an essential regulator of CNS myelination (Narayanan et al., 2009; Bercury et al., 2014; Lebrun-Julien et al., 2014; Wahl et al., 2014). In addition, mTOR signaling is a master switch that regulates translation, transcription, lipid synthesis, lysosomal biogenesis, energy metabolism, cell survival/metabolism, and cytoskeletal organization (Wahl et al., 2014). These off-target effects complicate interpretation of these drugs specifically on autophagy function in SCI.

In conclusion, SCI results in impaired autophagic flux acutely and continues until chronic intervals. Targeted deletion of Atg5 from OLs exacerbates the autophagic flux in OLs and correlates with poorer functional recovery after SCI and greater myelin loss. Drugs that could resolve autophagic flux and/or enhance autophagy could represent potential therapeutic approaches to treat SCI as well as other types of CNS trauma and extend to dysmyelinating and demyelinating diseases. While current genetic deletion data are conclusive and identify autophagy as a crucial homeostatic pathway that is required in OLs and exhibits a direct functional role in SCI pathogenesis, pharmacological verification of the functional role of autophagy after SCI will await more highly specific drugs. Moreover, those novel drugs that specifically only modulate autophagy are essential for further therapeutic clinical translation.

\section{References}

Alluin O, Delivet-Mongrain H, Gauthier MK, Fehlings MG, Rossignol S, Karimi-Abdolrezaee S (2014) Examination of the combined effects of chondroitinase $\mathrm{ABC}$, growth factors and locomotor training following compressive spinal cord injury on neuroanatomical plasticity and kinematics. PLoS One 9:e111072. CrossRef Medline

Bareyre FM (2008) Neuronal repair and replacement in spinal cord injury. J Neurol Sci 265:63-72. CrossRef Medline

Basso DM, Fisher LC, Anderson AJ, Jakeman LB, McTigue DM, Popovich PG (2006) Basso mouse scale for locomotion detects differences in recovery after spinal cord injury in five common mouse strains. J Neurotrauma 23:635-659. CrossRef Medline

B'chir W, Maurin AC, Carraro V, Averous J, Jousse C, Muranishi Y, Parry L, Stepien G, Fafournoux P, Bruhat A (2013) The eIF2a/ATF4 pathway is essential for stress-induced autophagy gene expression. Nucleic Acids Res 41:7683-7699. CrossRef Medline

Bercury KK, Dai J, Sachs HH, Ahrendsen JT, Wood TL, Macklin WB (2014) Conditional ablation of raptor or rictor has differential impact on oligodendrocyte differentiation and CNS myelination. J Neurosci 34: 4466-4480. CrossRef Medline

Cai Z, Zeng W, Tao K, E Z, Wang B, Yang Q (2015) Chaperone-mediated autophagy: roles in neuroprotection. Neurosci Bull 31:452-458. CrossRef Medline

Cao L, Fu M, Kumar S, Kumar A (2016) Methamphetamine potentiates HIV-1 gp 120-mediated autophagy via beclin-1 and Atg5/7 as a prosurvival response in astrocytes. Cell Death Dis 7:e2425. CrossRef Medline

Chen HC, Fong TH, Hsu PW, Chiu WT (2013) Multifaceted effects of rapamycin on functional recovery after spinal cord injury in rats through autophagy promotion, anti-inflammation, and neuroprotection. J Surg Res 179:e203-e210. CrossRef Medline

Coutts M, Keirstead HS (2008) Stem cells for the treatment of spinal cord injury. Exp Neurol 209:368-377. CrossRef Medline

D’Antonio M, Feltri ML, Wrabetz L (2009) Myelin under stress. J Neurosci Res 87:3241-3249. CrossRef Medline

Dietz V, Fouad K (2014) Restoration of sensorimotor functions after spinal cord injury. Brain 137:654-667. CrossRef Medline

Dincman TA, Beare JE, Saraswat-Ohri S, Whittemore SR (2012) Isolation of cortical mouse oligodendrocyte precursor cells. J Neurosci Methods 30: 219-226. CrossRef Medline

Doerflinger NH, Macklin WB, Popko B (2003) Inducible site-specific recombination in myelinating cells. Genesis 35:63-72. CrossRef Medline

Emery B (2010) Transcriptional and post-transcriptional control of CNS myelination. Curr Opin Neurobiol 20:601-607. CrossRef Medline

Enzmann GU, Benton RL, Talbott JF, Cao Q, Whittemore SR (2006) Functional considerations of stem cell transplantation therapy for spinal cord repair. J Neurotrauma 23:479-495. CrossRef Medline

Eskelinen EL (2005) Maturation of autophagic vacuoles in mammalian cells. Autophagy 1:1-10. CrossRef Medline

Eskelinen EL, Saftig P (2009) Autophagy: a lysosomal degradation pathway with a central role in health and disease. Biochim Biophys Acta 1793:664673. CrossRef Medline

Fawcett JW (2006) The glial response to injury and its role in the inhibition of CNS repair. Adv Exp Med Biol 557:11-24. CrossRef Medline

Fuss B, Afshari FS, Colello RJ, Macklin WB (2001) Normal CNS myelination in transgenic mice overexpressing MHC class I H-2I(d) in oligodendrocytes. Mol Cell Neurosci 18:221-234. CrossRef Medline

Gomez-Sanchez JA, Carty L, Iruarrizaga-Lejarreta M, Palomo-Irigoyen M, Varela-Rey M, Griffith M, Hantke J, Macias-Camara N, Azkargorta M, Aurrekoetxea I, De Juan VG, Jefferies HB, Aspichueta P, Elortza F, Aransay AM, Martínez-Chantar ML, Baas F, Mato JM, Mirsky R, Woodhoo A, et al. (2015) Schwann cell autophagy, myelinophagy, initiates myelin clearance from injured nerves. J Cell Biol 210:153-168. CrossRef Medline

Grummisch JA, Jadavji NM, Smith PD (2016) tPA promotes cortical neuron survival via mTOR-dependent mechanisms. Mol Cell Neurosci 74: 25-33. CrossRef Medline

Hagg T, Oudega M (2006) Degenerative and spontaneous regenerative processes after spinal cord injury. J Neurotrauma 23:264-280. CrossRef Medline

He Z, Liu H, Agostini M, Yousefi S, Perren A, Tschan MP, Mak TW, Melino G, Simon HU (2008) p73 regulates autophagy and hepatocellular lipid metabolism through a transcriptional activation of the ATG5 gene. Cell Death Diff 20:1415-1424. CrossRef Medline

Hesp ZC, Goldstein EA, Miranda CJ, Kaspar BK, McTigue DM (2015) Chronic oligodendrogenesis and remyelination after spinal cord injury in mice and rats. J Neurosci 35:1274-1290. CrossRef Medline

Hetman M, Kanning K, Cavanaugh JE, Xia Z (1999) Neuroprotection by brain-derived neurotrophic factor is mediated by extracellular-signalregulated kinase and phosphatidylinositol-3 kinase. J Biol Chem 274: 22569-22580. CrossRef Medline

Hu LY, Sun ZG, Wen YM, Cheng GZ, Wang SL, Zhao HB, Zhang XR (2010) ATP-mediated protein kinase B Akt/mammalian target of rapamycin $\mathrm{mTOR} / \mathrm{p} 70$ ribosomal $\mathrm{S} 6$ protein p70S6 kinase signaling pathway activation promotes improvement of locomotor function after spinal cord injury in rats. Neuroscience 169:1046-1062. CrossRef Medline

Jang SY, Shin YK, Park SY, Park JY, Rha SH, Kim JK, Lee HJ, Park HT (2015) Autophagy is involved in the reduction of myelinating Schwann cell cytoplasm during myelin maturation of the peripheral nerve. PLoS One 10: e0116624. CrossRef Medline

Kabeya Y, Mizushima N, Ueno T, Yamamoto A, Kirisako T, Noda T, Kominami E, Ohsumi Y, Yoshimori T (2000) LC3, a mammalian homologue 
of yeast Apg8p, is localized in autophagosome membranes after processing. EMBO J 19:5720-5728. CrossRef Medline

Kanno H, Ozawa H, Sekiguchi A, Itoi E (2009) Spinal cord injury induces upregulation of beclin 1 and promotes autophagic cell death. Neurobiol Dis 33:143-148. CrossRef Medline

Kanno H, Ozawa H, Sekiguchi A, Yamaya S, Itoi E (2011) Induction of autophagy and autophagic cell death in damaged neural tissue after acute spinal cord injury in mice. Spine 36:E1427-E1434. CrossRef Medline

Kouroku Y, Fujita E, Tanida I, Ueno T, Isoai A, Kumagai H, Ogawa S, Kaufman RJ, Kominami E, Momoi T (2007) ER stress (PERK/eIF2alpha phosphorylation) mediates the polyglutamine-induced LC3 conversion, an essential step for autophagy formation. Cell Death Differ 14:230-239. CrossRef Medline

Kroemer G, Mariño G, Levine B (2010) Autophagy and the integrated stress response. Mol Cell 40:280-293. CrossRef Medline

Kulbatski I, Mothe AJ, Parr AM, Kim H, Kang CE, Bozkurt G, Tator CH (2008) Glial precursor cell transplantation therapy for neurotrauma and multiple sclerosis. Prog Histochem Cytochem 43:123-176. CrossRef Medline

Kundu M, Thompson CB (2008) Autophagy: basic principles and relevance to disease. Annu Rev Pathol 3:427-455. CrossRef Medline

Lai Y, Hickey RW, Chen Y, Bayir H, Sullivan ML, Chu CT, Kochanek PM, Dixon CE, Jenkins LW, Graham SH, Watkins SC, Clark RS (2008) Autophagy is increased after traumatic brain injury in mice and is partially inhibited by the antioxidant gamma-glutamylcysteinyl ester. J Cereb Blood Flow Metab 28:540-550. CrossRef Medline

Larocca JN, Norton WT (2006) Isolation of myelin. Curr Protoc Cell Biol 33:3.25.1-3.25.19.

Lebrun-Julien F, Bachmann L, Norrmén C, Trötzmüller M, Köfeler H, Rüegg MA, Hall MN, Suter U (2014) Balanced mTORC1 activity in oligodendrocytes is required for accurate CNS myelination. J Neurosci 34:84328448. CrossRef Medline

Lin W, Popko B (2009) Endoplasmic reticulum stress in disorders of myelinating cells. Nat Neurosci 12:379-385. CrossRef Medline

Liu CL, Chen S, Dietrich D, Hu BR (2008) Changes in autophagy after traumatic brain injury. J Cereb Blood Flow Metab 28:674-683. CrossRef Medline

Liu J, Xia H, Kim M, Xu L, Li Y, Zhang L, Cai Y, Norberg HV, Zhang T, Furuya T, Jin M, Zhu Z, Wang H, Yu J, Li Y, Hao Y, Choi A, Ke H, Ma D, Yuan J (2011) Beclin 1 controls the levels of $p 53$ by regulating the deubiquitination activity of USP10 and USP13. Cell 147:223-234. CrossRef Medline

Liu S, Sarkar C, Dinizo M, Faden AI, Koh EY, Lipinski MM, Wu J (2015) Disrupted autophagy after spinal cord injury is associated with ER stress and neuronal cell death. Cell Death Dis 6:e1582. CrossRef Medline

Lv X, Jiang H, Li B, Liang Q, Wang S, Zhao Q, Jiao J (2014) The crucial role of Atg5 in cortical neurogenesis during early brain development. Sci Rep 4:6010. CrossRef Medline

Magnuson DS, Lovett R, Coffee C, Gray R, Han Y, Zhang YP, Burke DA (2005) Functional consequences of lumbar spinal cord contusion injuries in the adult rat. J Neurotrauma 22:529-543. CrossRef Medline

Mallon BS, Shick HE, Kidd GJ, Macklin WB (2002) Proteolipid promoter activity distinguishes two populations of $\mathrm{NG}_{2}$-positive cells throughout neonatal cortical development. J Neurosci 22:876-885. CrossRef Medline

Mariño G, Madeo F, Kroemer G (2011) Autophagy for tissue homeostasis and neuroprotection. Curr Opin Cell Biol 23:198-206. CrossRef Medline

Messer JS (2017) The cellular autophagy/apoptosis checkpoint during inflammation. Cell Mol Life Sci 74:1281-1296. CrossRef Medline

Miller RH (2002) Regulation of oligodendrocyte development in the vertebrate CNS. Prog Neurobiol 67:451-467. CrossRef Medline

Narayanan SP, Flores AI, Wang F, Macklin WB (2009) Akt signals through the mammalian target of rapamycin pathway to regulate CNS myelination. J Neurosci 29:6860-6870. CrossRef Medline

Penas C, Guzmán MS, Verdú E, Forés J, Navarro X, Casas C (2007) Spinal cord injury induces endoplasmic reticulum stress with different cell-type dependent response. J Neurochem 102:1242-1255. CrossRef Medline

Pengo N, Scolari M, Oliva L, Milan E, Mainoldi F, Raimondi A, Fagioli C, Merlini A, Mariani E, Pasqualetto E, Orfanelli U, Ponzoni M, Sitia R, Casola S, Cenci S (2013) Plasma cells require autophagy for sustainable immunoglobulin production. Nat Immunol 14:298-305. CrossRef Medline
Pla A, Pascual M, Guerri C (2016) Autophagy constitutes a protective mechanism against ethanol toxicity in mouse astrocytes and neurons. PLoS One 11:e0153097. CrossRef Medline

Radad K, Moldzio R, Al-Shraim M, Kranner B, Krewenka C, Rausch WD (2015) Recent advances in autophagy-based neuroprotection. Expert Rev Neurother 15:195-205. CrossRef Medline

Rowland JW, Hawryluk GW, Kwon B, Fehlings MG (2008) Current status of acute spinal cord injury pathophysiology and emerging therapies: promise on the horizon. Neurosurg Focus 25:E2. CrossRef Medline

Rubinsztein DC, Gestwicki JE, Murphy LO, Klionsky DJ (2007) Potential therapeutic applications of autophagy. Nat Rev Drug Discov 6:304-312. CrossRef Medline

Sano R, Reed JC (2013) ER stress-induced cell death mechanisms. Biochim Biophys Acta 1833:3460-3470. CrossRef Medline

Saraswat Ohri S, Maddie MA, Zhao Y, Qiu MS, Hetman M, Whittemore SR (2011) Attenuating the endoplasmic reticulum stress response improves functional recovery after spinal cord injury. Glia 59:489-1502. CrossRef Medline

Saraswat Ohri S, Hetman M, Whittemore SR (2013) Restoring endoplasmic reticulum homeostasis improves functional recovery after spinal cord injury. Neurobiol Dis 58:29-37. CrossRef Medline

Scheff SW, Rabchevsky AG, Fugaccia I, Main JA, Lumpp JE Jr (2003) Experimental modeling of spinal cord injury characterization of a force-defined injury device. J Neurotrauma 20:179-193. CrossRef Medline

Sekiguchi A, Kanno H, Ozawa H, Yamaya S, Itoi E (2012) Rapamycin promotes autophagy and reduces neural tissue damage and locomotor impairment after spinal cord injury in mice. J Neurotrauma 29:946-956. CrossRef Medline

Shen C, Xian W, Zhou H, Chen L, Pei Z (2016) Potential protective effects of autophagy activated in $\mathrm{MPP}^{+}$treated astrocytes. Exp Ther Med 12:28032810. CrossRef Medline

Shi X, Xu L, Doycheva DM, Tang J, Yan M, Zhang JH (2017) Sestrin2, as a negative feedback regulator of $\mathrm{mTOR}$, provides neuroprotection by activation AMPK phosphorylation in neonatal hypoxic-ischemic encephalopathy in rat pups. J Cereb Blood Flow Metab 37:1447-1460. CrossRef Medline

Simons M, Nave KA (2016) Oligodendrocytes: myelination and axonal support. Cold Spring Harbor Perspect Biol 8:a020479. CrossRef Medline

Su P, Zhang J, Wang D, Zhao F, Cao Z, Aschner M, Luo W (2016) The role of autophagy in modulation of neuroinflammation in microglia. Neuroscience 319:155-167. CrossRef Medline

Tanabe F, Yone K, Kawabata N, Sakakima H, Matsuda F, Ishidou Y, Maeda S, Abematsu M, Komiya S, Setoguchi T (2011) Accumulation of p62 in degenerated spinal cord under chronic mechanical compression. Autophagy 7:1462-1471. CrossRef Medline

Tang P, Hou H, Zhang L, Lan X, Mao Z, Liu D, He C, Du H, Zhang L (2014) Autophagy reduced neuronal damage and promotes locomotor recovery via inhibition of apoptosis after spinal cord injury in rats. Mol Neurobiol 49:288-290. CrossRef Medline

Tyler WA, Gangoli N, Gokina P, Kim HA, Covey M, Levison SW, Wood TL (2009) Activation of the mammalian target of rapamycin (mTOR) is essential for oligodendrocyte differentiation. J Neurosci 29:6367-6378. CrossRef Medline

Valenzuela V, Collyer E, Armentano D, Parsons GB, Court FA, Hetz C (2012) Activation of the unfolded protein response enhances motor recovery after spinal cord injury. Cell Death Dis 16:e272. CrossRef Medline

Vázquez P, Arroba AI, Cecconi F, de la Rosa EJ, Boya P, de Pablo F (2012) Atg5 and Ambral differentially modulate neurogenesis in neural stem cells. Autophagy 8:187-199. CrossRef Medline

Wahl SE, McLane LE, Bercury KK, Macklin WB, Wood TL (2014) Mammalian target of rapamycin promotes oligodendrocyte differentiation, initiation and extent of CNS myelination. J Neurosci 34:4453-4465. CrossRef Medline

Walker CL, Walker MJ, Liu NK, Risberg EC, Gao X, Chen J, Xu XM (2012) Systemic bisperoxovanadium activates Akt/mTOR, reduces autophagy, and enhances recovery following cervical spinal cord injury. PLoS One 7:e30012. CrossRef Medline

Wang S, Li B, Qiao H, Lv X, Liang Q, Shi Z, Xia W, Ji F, Jiao J (2014) Autophagyrelated gene Atg5 is essential for astrocyte differentiation in the developing mouse cortex. EMBO Rep 15:1053-1061. CrossRef Medline

Wen YD, Sheng R, Zhang LS, Han R, Zhang X, Zhang XD, Han F, Fukunaga K, 
Qin ZH (2008) Neuronal injury in rat model of permanent focal cerebral ischemia is associated with activation of autophagic and lysosomal pathways. Autophagy 4:762-769. CrossRef Medline

Wight PA, Duchala CS, Readhead C, Macklin WB (1993) A myelin proteolipid protein-LacZ fusion protein is developmentally regulated and targeted to the myelin membrane in transgenic mice. J Cell Biol 123:443454. CrossRef Medline

Williams A, Jahreiss L, Sarkar S, Saiki S, Menzies FM, Ravikumar B, Rubinsztein DC (2006) Aggregate-prone proteins are cleared from the cytosol by autophagy: therapeutic implications. Curr Top Dev Biol 76:89-101. CrossRef Medline

Yin Y, Sun G, Li E, Kiselyov K, Sun D (2017) ER stress and impaired au- tophagy flux in neuronal degeneration and brain injury. Ageing Res Rev 34:3-14. CrossRef Medline

Yoon C, Tuszynski MH (2012) Frontiers of spinal cord and spine repair: experimental approaches for repair of spinal cord injury. Adv Exp Med Biol 760:1-15. Medline

Yorimitsu T, Nair U, Yang Z, Klionsky DJ (2006) Endoplasmic reticulum stress triggers autophagy. J Biol Chem 281:30299-30304. CrossRef Medline

Zhang XJ, Chen S, Huang KX, Le WD (2013) Why should autophagic flux be assessed? Acta Pharmacol Sin 34:595-599. CrossRef Medline

Zhong Z, Sanchez-Lopez E, Karin M (2016) Autophagy, inflammation, and immunity: a troika governing cancer and its treatment. Cell 166:288-298. CrossRef Medline 